Review

\title{
Impact of Conventional and Atypical MAPKs on the Development of Metabolic Diseases
}

\author{
Toufic Kassouf (1) and Grzegorz Sumara * \\ Dioscuri Centre for Metabolic Diseases, Nencki Institute of Experimental Biology, Polish Academy of Sciences, \\ 3 Pasteur Street, 02-093 Warsaw, Poland; t.kassouf@nencki.edu.pl \\ * Correspondence: g.sumara@nencki.edu.pl
}

Received: 1 July 2020; Accepted: 26 August 2020; Published: 29 August 2020

\begin{abstract}
The family of mitogen-activated protein kinases (MAPKs) consists of fourteen members and has been implicated in regulation of virtually all cellular processes. MAPKs are divided into two groups, conventional and atypical MAPKs. Conventional MAPKs are further classified into four sub-families: extracellular signal-regulated kinases 1/2 (ERK1/2), c-Jun N-terminal kinase (JNK1, 2 and 3), p38 $(\alpha, \beta, \gamma, \delta)$, and extracellular signal-regulated kinase 5 (ERK5). Four kinases, extracellular signal-regulated kinase 3, 4, and 7 (ERK3, 4 and 7) as well as Nemo-like kinase (NLK) build a group of atypical MAPKs, which are activated by different upstream mechanisms than conventional MAPKs. Early studies identified JNK1/2 and ERK1/2 as well as p38 $\alpha$ as a central mediators of inflammation-evoked insulin resistance. These kinases have been also implicated in the development of obesity and diabetes. Recently, other members of conventional MAPKs emerged as important mediators of liver, skeletal muscle, adipose tissue, and pancreatic $\beta$-cell metabolism. Moreover, latest studies indicate that atypical members of MAPK family play a central role in the regulation of adipose tissue function. In this review, we summarize early studies on conventional MAPKs as well as recent findings implicating previously ignored members of the MAPK family. Finally, we discuss the therapeutic potential of drugs targeting specific members of the MAPK family.
\end{abstract}

Keywords: obesity; diabetes; MAPKs; ERK1/2; JNKs; p38; ERK5; ERK3; ERK7; NLK

\section{Introduction}

Mitogen-activated protein kinases (MAPKs) are protein Ser/Thr kinases that convert a variety of extracellular signals into a wide range of cellular responses. In mammals, 14 MAPKs, including both conventional and atypical MAPKs, have been characterized and divided into seven subfamilies [1,2]. Conventional MAPKs comprise four subfamilies of MAPKs: the extracellular signal-regulated kinases 1/2 (ERK1/2), c-Jun amino (N)-terminal kinases 1/2/3 (JNK1/2/3), p38 isoforms (p38 $\alpha, \beta$, $\gamma$, and $\delta$ ), and ERK5. Activation of each group of conventional MAPKs depends on a set of two upstream, evolutionarily conserved, sequentially acting kinases [2]. Each MAPK is activated by dual phosphorylation of a tripeptide motif (Thr-X-Tyr) located in the activation loop (T-loop). This phosphorylation is mediated by a MAPK kinase (MAPKK) that is activated by phosphorylation by an upstream MAPKK kinase (MAPKKK) [2]. Atypical, those having nonconforming particularities, MAPKs on the other hand comprise ERK3/4, ERK7, and Nemo-like kinase (NLK). In contrast to conventional MAPKs, they are not organized into classical three-tiered kinase cascades, and less is known about the exact molecular mechanisms involved in their activation [1,2].

MAPK signaling pathways regulate a variety of cellular activities including proliferation, differentiation, survival, and death [2]. Consistent with their critical roles in key cellular activities, deregulation of these pathways has been implicated in the pathogenesis of many human diseases including Alzheimer's disease, Parkinson's disease, amyotrophic lateral sclerosis, and various types of 
cancers [3]. MAPKs are also required for an array of metabolic events, and consequently inappropriate MAPK signaling contributes to the development of several metabolic diseases including obesity, type 2 diabetes (T2D) as well as non-alcoholic fatty liver disease (NAFLD) and atherosclerosis [4-6].

In this review, we discuss the relationship between conventional and atypical MAPK-signaling mechanisms that underlay metabolism and metabolic disorders.

\section{The Conventional MAPKs}

\subsection{ERK1/2 Kinases}

ERK1 and ERK2, also known as MAPK3 and MAPK1 respectively, are evolutionarily conserved kinases encoded by two separate genes and expressed to different extent in all tissues, with particularly high levels in the brain, skeletal muscle, thymus, and heart [7]. ERK1/2 are activated by growth factors, ligands for heterotrimeric G protein-coupled receptors (GPCRs), cytokines, osmotic stress, microtubule disorganization, and in response to insulin [2]. Their main initiating kinases (MAPKKK) are members of the RAF family, which include serine/threonine-protein kinase A-raf (ARAF), BRAF, and CRAF, and are often activated as a result of their interaction with active GTP-bound RAS proteins. Once activated, RAF kinases phosphorylate and activate components of the MAPKK module, such as MEK1 and MEK2, which in turn activate two MAPKs, ERK1, and ERK2, through phosphorylation of both tyrosine and threonine residues present in a conserved tripeptide motif (Thr-Glu-Tyr) within their activation loop [2]. Through the phosphorylation of their targets, ERK1 and ERK2 are involved in a wide variety of cellular processes including proliferation, inflammation, and cellular metabolism (reviewed in [2,8]). Upon activation, ERK1/2 phosphorylate a large number of substrates localized in nucleus and cytosol (Table 1). In the cytosol, ribosomal S6 kinase (RSK) family members, which are known to inactivate apoptotic proteins and to promote cell proliferation, represent one of the major substrates for ERK1/2 [9]. MAPK-interacting kinases 1/2 (MNK1/2) and Mitogen- and stress-activated kinase 1/2 (MSK1/2) are also important downstream targets of the ERK1/2 [10,11]. MNK1/2 control translation of mRNA [11]. MSKs phosphorylate multiple substrates, including cAMP-responsive element-binding protein (CREB) and Histone $\mathrm{H3}$, and their major role is the regulation of specific subsets of immediate early genes (IEG) [10]. In the nucleus, ERK1/2 phosphorylate and activate the transcription factor ETS domain-containing protein Elk-1 (Elk-1), which mediates the transcription of c-Fos [12]. ERK1/2 are also known to stabilize c-Fos and to prevent its degradation, allowing c-Fos to associate with c-Jun and form transcriptionally active complexes. c-Jun/c-Fos dimer promote expression of cyclin D1, a protein that interacts with cyclin-dependent kinases (CDKs) and permits G1/S transition and cell cycle progression $[13,14]$. ERK1/2 are also known to mediate cell motility by phosphorylating actin-binding proteins implicated in cytoskeletal remodeling [15]. They are also involved in actin polymerization via their interaction with different actin regulatory proteins [16]. Additionally, ERK1/2 are implicated in the development of multiple types of cancers (reviewed in $[17,18]$ ). Consistent with their critical roles in tumorigenesis, targeting these enzymes present nowadays an outstanding interest for different therapeutic purposes [18].

In vivo ERK1 or ERK2 abrogation leads to different phenotypes, demonstrating different roles for the two isoforms. Disruption of the Erk2 locus results in embryonic lethality early in mouse development after the implantation phase. On the contrary, mice deficient of Erk1 in the whole body are viable and fertile [19]. Interestingly, transgenic expression of ERK1 fully rescues the embryonic and placental developmental defects resulting from the loss of ERK2, suggesting functional redundancy during development [20]. Most importantly, ERK1/2 pathways are central in regulation of metabolism in the multiple organs. 
Table 1. Conventional MAPKs signaling cascades and their major substrates.

\begin{tabular}{|c|c|c|c|c|}
\hline Stimulus & МАРККК & MAPKK & MAPK & Substrates and Biological Functions \\
\hline $\begin{array}{l}\text { Growth factors, ligand for GPCRs, } \\
\text { cytokines, osmotic stress, microtubule } \\
\text { disorganization, and insulin. }\end{array}$ & $\begin{array}{l}\text { RAF family } \\
\text { (ARAF, BRAF, } \\
\text { CRAF) }\end{array}$ & MEK $1 / 2$ & ERK1/2 & $\begin{array}{l}\text { RSK family (gene transcription, cell proliferation, growth, and survival) } \\
\text { MSK1/2 (gene transcription, nucleosome dynamics) } \\
\text { MNK1/2 (mRNA translation) } \\
\text { Elk-1 (transcription of c-Fos) } \\
\text { c-Fos (transcription) } \\
\text { Synapsin I, focal adhesion kinase [FAK] and myosin light-chain kinase (actin } \\
\text { polymerization) } \\
\text { Neurofilaments and paxillin (cytoskeleton organization) } \\
\text { CD120a, spleen tyrosine kinase [SYK], and calnexin (plasma membrane dynamics) } \\
\text { Death-associated protein kinase [DAPK] (cell death) } \\
\text { Tuberous sclerosis complex } 2 \text { [TSC2] (nutrient sensing) } \\
\text { Nuclear factor of activated T-cells [NF-AT], myocyte enhancer factor } 2 \text { [MEF2] and } \\
\text { c-Myc (transcription) } \\
\text { Signal transducer and activator of transcription } 3 \text { [STAT3] (signaling) }\end{array}$ \\
\hline $\begin{array}{l}\text { Stress (hypoxia, UV, and ionizing } \\
\text { radiation), cytokines, growth factors, } \\
\text { pathogens, toxins, drugs, metabolic } \\
\text { changes (obesity and hyperlipidaemia). }\end{array}$ & $\begin{array}{l}\text { MEKK1 to }-4 \text { Mixed lineage kinase } 1 / 2 / 3 \\
\text { [MLK1/2/3] } \\
\text { Tumor progression locus } 2 \\
\text { [Tpl-2] } \\
\text { Delta-like non-canonical Notch ligand [DLK] } \\
\text { TAO1/2 } \\
\text { TGF- } \beta \text {-activated kinase } 1 \text { [TAK1] } \\
\text { Apoptosis signal-regulating kinase } 1 / 2 \\
\text { [ASK1/2] }\end{array}$ & $\begin{array}{l}\text { MKK4 } \\
\text { MKK7 }\end{array}$ & JNKs & $\begin{array}{l}\text { c-jun, (transcription, cell cycle and apoptosis) } \\
\text { BH3-only family of Bcl2 proteins (apoptosis) } \\
\text { p53 (apoptosis) } \\
\text { Activating transcription factor } 2 \text { [ATF-2], nuclear factor of activated T-cells, } \\
\text { cytoplasmic 1 [NF-ATc1], Elk-1, Heat shock factor protein 1 [HSF-1], STAT3, c-Myc, } \\
\text { JunB (transcription) }\end{array}$ \\
\hline $\begin{array}{l}\text { Oxidative stress, UV irradiation, } \\
\text { hypoxia, ischemia, inflammatory } \\
\text { cytokines, ligand for GPCRs, and Rho } \\
\text { family GTPases. }\end{array}$ & $\begin{array}{l}\text { MEKK1 to }-3 \text { MLK2/3 ASK1 } \\
\text { Tpl-2 } \\
\text { TAK1 } \\
\text { TAO1/2 }\end{array}$ & $\begin{array}{l}\text { MKK3 } \\
\text { MKK6 } \\
\text { TAK1 binding } \\
\text { protein } 1 \text { [TAB1] } \\
\text { ZAP70 } \\
\text { LCK }\end{array}$ & $\mathrm{p} 38 \mathrm{~s}$ & $\begin{array}{l}\text { MSK1/2 (gene transcription, nucleosome response) } \\
\text { MNK1/2 (mRNA translation) } \\
\text { p53 (preventing p53 proteasomal degradation) } \\
\text { ATF (regulation of ER stress response) } \\
\text { ATF-2 and Nuclear factor NF-kappa-B [NF-KB] (expression of inflammatory } \\
\text { cytokines) } \\
\text { Elk-1 (transcription) } \\
\text { protein kinase D1 [PKD1] (Trans-Golgi dynamics, signaling) }\end{array}$ \\
\hline $\begin{array}{l}\text { Growth factors, inflammatory } \\
\text { cytokines, oxidative and osmotic } \\
\text { stresses, ischaemia, and hypoxia. }\end{array}$ & MEKK2 MEKK3 & MEK5 & ERK5 & $\begin{array}{l}\text { SGK (kinase) } \\
\text { MEF2, Elk-1 and Sap1a (transcription) }\end{array}$ \\
\hline
\end{tabular}




\subsubsection{The Role of ERK1/2 in the Liver}

The liver plays a major role in maintaining glucose homeostasis by releasing glucose into the circulation via glycogenolysis and gluconeogenesis during fasting [21]. Moreover, hepatic lipid metabolism largely determines triglycerides (TG) and cholesterol levels in the organism. In vivo studies showed an increased ERK1/2 activity in the liver of both, diet-induced and genetically obese mice [22]. Additionally, sustained hepatic ERK1/2 activity in the livers of lean mice perturbed glucose homeostasis, decreased energy expenditure and induced systemic insulin resistance [22]. Moreover, knocking down ERK1/2 expression in the liver of obese mice improved systemic insulin and glucose tolerance [22]. Consistent with these results, caloric restriction resulted in improved insulin sensitivity, which was accompanied by decreased hepatic activities of ERK1/2 kinases [23]. Indeed, obese Erk1 knockout mice exhibited high degree of phosphorylation of liver's MEK, the upstream regulator of ERK1/2. This phenomenon was associated with increased acetyl-CoA carboxylase 1 (ACC1) and fatty acid synthase (FAS) mRNA expression, indicating high lipogenesis, and decreased peroxisome proliferator-activated receptor $\alpha(\mathrm{PPAR} \alpha)$ and carnitine palmitoyltransferase $1 \beta(\mathrm{CPT} 1 \beta)$ mRNA level suggesting a lower fatty acid (FA) oxidation [24].

Several potential pathways regulating systemic glucose and lipid metabolism, as well as insulin sensitivity via ERK1/2 were also further investigated. Constitutive activation of the ERK1/2 pathway was shown to suppress the expression of glucose-6-phosphatase (G6Pase) gene, a key enzyme in de novo glucose synthesis, and to decrease glucose output in hepatic cells [25]. The decreased expression of G6Pase gene is likely due to ERK1/2-mediated phosphorylation and cytosolic retention of the transcription factor Forkhead box O1 (FOXO1) [22]. Insulin-induced cytokine production in macrophages has also been implicated in the induction of insulin resistance in hepatocytes through ERK1/2 and Inhibitor of $\mathrm{KB}$ kinase $\beta(\operatorname{IKK} \beta)$ activation. Mechanistically, activation of both kinases results in an inhibitory serine phosphorylation of the insulin receptor substrate (IRS) which blocks insulin action [26]. Additionally, fibroblast growth factor 21 (FGF21) was shown to act directly on the liver to stimulate phosphorylation of fibroblast growth factor receptor substrate 2 (FRS2) and ERK1/2. In vivo, acute FGF21 treatment induced hepatic expression of key regulators of gluconeogenesis, lipid metabolism, and ketogenesis [27]. Furthermore, overexpression of Hepassocin (HPS), a liver-derived protein, promotes lipid accumulation through an ERK1/2-mediated pathway [28], and recombinant HPS administration aggravates insulin signaling to induce insulin resistance through an ERK1/2-mediated signaling in hepatocytes [29]. In primary rodent hepatocytes, conjugated bile acids activate sphingosine-1-phosphate receptor 2 (S1PR2), which further activates the downstream ERK1/2 and AKT signaling pathways. Activation of ERK1/2 and AKT signaling pathway plays an important role in the regulation of hepatic glucose and lipid metabolism [30,31]. Moreover, p53 seems also to be involved in improving insulin sensitivity of hepatic cells through the inhibition of NF- $\mathrm{KB}$ and ERK1/2/p38 MAPK pathways [32]. However, the function of p53 with respect to insulin resistance appears to be highly controversial [32]. Similar to p53, serum- and glucocorticoid-regulated kinase 1 (SGK1) improves insulin sensitivity in the liver by inhibiting ERK1/2 activity [33].

Therefore, ERK1/2 kinases are the central regulators of hepatic glucose and lipid metabolism.

\subsubsection{ERK1/2 Promote Adipocyte Acquisition and Preserves Their Function}

Adipose tissue is the central storage organ in the body. White, beige, and brown are the three major types of adipocytes, which play different physiological roles in whole-body energy homeostasis [34]. The main function of white adipocytes is to store excess energy as TGs for utilization during nutrient shortage. Beige and brown adipocytes dissipate the chemical energy stored in TGs as heat to preserve core temperature via the uncoupling of FA oxidation from ATP production, mediated by the uncoupling protein 1 (UCP1). During the time of increase, energy demand adipocytes can hydrolyze TGs into FAs and glycerol in the process of lipolysis. Lipolysis is tightly regulated by ERK1/2 [35]. In fact, ERK1/2 activity is significantly increased in adipose tissue of diet-induced obese mice. ERK1 deficient mice are protected from developing high-fat diet (HFD)-induced obesity, 
which is possibly due to impaired in vivo adipogenesis [36]. These observations are in contradiction to a recently published study showing that Erk1 ${ }^{-/-}$mice, fed with HFD, were more obese than control animals [24]. HFD-induced obesity was associated with high fasting glucose and insulin concentrations, suggesting that a high degree of obesity in these animals might be caused, in part, by high insulin resistance. Though a plausible explanation for these observations is not available, it is worth noting the difference in FA composition of the diets used by both studies. In the genetic model of the obesity and hyperphagia (mice deficient for leptin function—ob/ob mice) deficiency of ERK1 results in partial protection from insulin resistance and liver steatosis due to the decreased adipose tissue inflammation and induction of muscle glucose uptake [37]. Interestingly, mouse primary adipocytes selectively express ERK2 but have undetectable levels of ERK1. Adipocyte-specific ERK2 knock-out mice exhibit decreased rates of lipolysis [35]. Mice with ERK2 inactivation or inhibition also fail to appropriately activate thermogenesis and maintain body temperature upon cold challenge due to lack of substrate availability. Indeed, ERK1/2 activation in adipocytes seems to be a critical regulatory step in the enhanced adipocyte lipolysis. Catecholamine-stimulated lipolysis in adipocytes is primarily a $\beta$-adrenergic and cAMP-dependent event. $\beta 3$-adrenergic receptor ( $\beta 3 \mathrm{AR}$ ) regulates lipolysis through both, cAMP-dependent protein kinase A (PKA) and ERK1/2, by direct recruitment and activation of Src kinase [38]. A recent study showed that in vivo inhibition of the MEK/ERK pathway alters lipolysis in adipose tissue by decreasing $\beta 3$-adrenergic receptor ( $\beta 3 \mathrm{AR})$ phosphorylation at serine 247 and subsequent downstream phosphorylation events that control the release of free FA (FFA) [35]. Furthermore, the activation of ERK1/2 by tumor necrosis factor $\alpha$ (TNF $\alpha$ ) leads to increased basal lipolysis due to the downregulation of perilipin at mRNA and protein levels [39]. Perilipin coats lipid storage droplets in adipocytes, thereby protecting them until they can be broken down by hormone-sensitive lipase [40]. ERK1/2 also regulates lipolysis by the phosphorylation of hormone-sensitive lipase at Ser 600, increasing catalytic activity and the release of FFA from adipocytes [41]. Moreover, the activation of the Fas receptor, member of the TNF receptor, leads to ERK1/2-mediated lipolysis, which may be triggered by a Fas-induced increase in intracellular calcium levels and hence, autophosphorylation of the CaMKII [42].

ERK1/2 are also required in the early steps of adipogenesis [43] and need to be subsequently inhibited to prevent peroxisome proliferator-activated receptor $\gamma(\operatorname{PPAR} \gamma)$ phosphorylation and to enhance terminal differentiation [44]. PPAR $\gamma$ is the main driver of adipocyte differentiation. PPAR $\gamma$ phosphorylation by ERK1/2 and JNKs results in decreased transcriptional activity, thereby attenuating differentiation [45].

FGF21 has anti-inflammatory effects on preadipocytes; these effects are mediated by the fibroblast growth factor receptor substrate 2/ERK1/2 signaling pathway [46]. Moreover, ERK1/2 seem also to be implicated in other mechanisms recently identified to induce adipogenesis, including the secretion of Caveolin-1 (Cav-1), a putative adipogenesis enhancer, from adipocytes [47], as well as the Fibrinogen-like-protein 1 (FGL1)/ CCAAT/enhancer-binding protein $\beta$ (C/EBP $\beta$ ) pathway [48]. Finally, Erk1/2 present also critical roles in promoting norepinephrine (NE)- and basic fibroblast growth factor (bFGF)-dependent survival of brown adipocytes [49] and in browning of white adipocyte [50]. Angiotensin type 2 receptor (AT2R) stimulates white adipocyte browning through ERK1/2, leading to enhanced UCP1 expression and exhibition of brown-like phenotypes [50].

To sum up, ERK1/2 promote adipogenesis, lipolysis, and thermogenesis in different depots of adipose tissue.

\subsubsection{ERK1/2 Promote Inflammation during Obesity}

Obesity induces infiltration of immune cells, promoting chronic low-grade inflammation and eventually leading to adipocyte death. Moreover, circulating proinflammatory cytokines, and FFAs derived from the inflamed adipose tissue, impair insulin sensitivity in the periphery, which is the major cause for the development of T2D [51]. Macrophage-elicited metabolic inflammation and adipocyte-macrophage interaction are in fact key factors in obesity [52]. Conventional MAPKs, 
including ERK1/2, JNKs, and p38s, are essential regulators of adipose tissue inflammation, linking TNF $\alpha$ signaling to activation of downstream transcriptional programs that promote pro-inflammatory gene expression [53,54]. While the critical role of both ERK1 and ERK2 in the process of positive selection and maturation of CD4+ and CD8+ T cell [55] and macrophage development [56] is well established, there is also supporting evidence that underlays their role in metabolic inflammation. In the context of macrophage-adipose cell interactions, several studies revealed that macrophage-conditioned medium (MaCM), collected under basal conditions, protects preadipocytes from apoptosis in a platelet-derived growth factor (PDGF)-dependent manner [57,58]. MaCM-induced preadipocyte survival depends on signaling through Akt, ERK1/2, and reactive oxygen species (ROS) [58]. ERK1/2 act also as an important signaling mediator for the inhibitory effect of MaCM on TG accumulation during adipogenesis [59]. Of note, FGF21 acts on adipocytes in an autocrine manner to promote the expression and secretion of chemoattractant C-C motif chemokine ligand 11 (CCL11) via activation of ERK1/2, which drives recruitment of eosinophils into subcutaneous white adipose tissue (WAT), leading to increased accumulation of M2 macrophages, and proliferation and commitment of adipocyte precursors into beige adipocytes [60]. Dual specificity phosphatases (DUSPs), which are ERK1/2 phosphatases, inactivate ERK1/2 through dephosphorylation and can thus inhibit inflammatory gene expression. For example, in epididymal WAT and in response to diet-induced obesity, DUSP5 functions as the feedback regulator of TNF $\alpha$-evoked ERK1/2 signaling, which results in increased inflammatory gene expression [61]. Finally, inflammation induced by macrophage-derived cytokines, interleukin-1 $\beta$ (IL-1 $\beta$ ) and TNF $\alpha$, could suppress the induction of UCP1 expression in adipocytes through ERK1/2 activation $[62,63]$.

Taken together, ERK1/2 determine inflammatory response during obesity.

\subsubsection{ERK1/2 Drive Insulin Production in Pancreatic $\beta$-Cells}

Diabetes is a complex metabolic disorder caused by insufficient insulin action in the peripheral tissues and defective insulin secretion from the pancreatic $\beta$-cells. Insulin is the most potent hormone promoting TG synthesis and inhibiting lipolysis [64]. Several studies have suggested a positive regulatory role of the ERK1/2 signaling in glucose-stimulated insulin secretion and $\beta$-cell survival $[65,66]$. Physiological concentrations of glucose that lead to $\mathrm{Ca}^{2+}$ entry and insulin secretion activate ERK1/2 in pancreatic $\beta$-cell [67], where they are required for insulin gene transcription [68] and insulin release from pancreatic $\beta$-cells and rodent pancreatic islets [69]. Interestingly, however, it is ERK1 specifically, and not ERK2 that seems to be necessary for glucose-induced full activation of key proteins involved in $\beta$-cell function, namely MSK1 and CREB [70]. Indeed, MSK1 and CREB activities were restored when ERK1 was reintroduced in $E r k 1^{-/}$mouse $\beta$-cells, but not when ERK2 was overexpressed, which indicates a specific role for ERK1 in these processes. However, ERK2 activity is likely to be sufficient for insulin gene expression and the first phase of glucose-stimulated insulin secretion [70]. The ERK1/2 signaling module is typically activated by an upstream small G-protein activation (Ras), which in turn activates Raf (MAPKKK) and MEK1/2 (MAPKK). Glucose-induced ERK1/2 activation was inhibited in pancreatic $\beta$-cells expressing kinase-negative mutants of Ras and Raf kinases [71]. However, Raf-MEK-ERK signaling axis can be also activated by Rap1, another small GTPase, in human pancreatic $\beta$-cells upon stimulation with glucose and GLP-1 [72]. Moreover, increased concentrations of FAs in blood, and in particular saturated FAs (e.g., stearic and palmitic acid), are known to be one of the main factors responsible for pancreatic $\beta$-cell death in T2D [65]. The effects of saturated FAs on ERK1/2 activity and their pro-apoptotic or pro-survival role in $\beta$-cells tend to be rather contradictory [65]. However, in the presence of MEK1 inhibitor, the activity of adiponectin, a pancreatic $\beta$-cells pro-survival hormone secreted by adipocytes, was blocked. These findings suggest pro-survival function of ERK1/2 module in pancreatic $\beta$-cells [73].

Taken together, ERK1/2 promote pancreatic $\beta$-cell mass and insulin secretion. 


\subsubsection{ERK1/2 Promote Skeletal Muscle Acquisition and Metabolism}

Skeletal muscle is the primary site for glucose uptake and storage in the form of glycogen, and, accordingly, plays a key role in the control of the whole body glucose metabolism [74]. Insulin and muscle contraction activate conventional MAPKs (ERK1/2, JNKs, and p38s) signaling in skeletal muscle [75]. Insulin-mediated responses on MAPK signaling are impaired in skeletal muscle from obese mice, whereas the effect of contraction is generally well preserved [76]. Animals lacking muscle ERK1/2 displayed impaired postnatal growth, muscle weakness, and a shorter life span [77]. Their muscles displayed fragmented neuromuscular synapses and a mixture of modest fiber atrophy and loss. On the other hand, muscle atrophy during cachexia was associated with mitochondrial depletion and up-regulation of ERK1/2 and p38 MAPKs activity [78]. Moreover, blocking of the activity of ERK1/2 pathways by using MEK1 inhibitors prevents chemotherapy-related cachexia [78]. Altogether, these data indicate that ERK1/2 promote developmental processes in muscles, but these kinases also mediate pathological processes in muscular fibers evoked medications used during chemotherapy.

ERK1/2 are involved in various metabolic mechanisms at skeletal muscle level. Palmitic acid (PA)-mediated glucose uptake in skeletal muscle cells is stimulated by the binding of PA to cell surface and followed by activation of PI3K/ERK1/2 pathway [79]. Furthermore, complement C1q/TNF-related protein 6 (CTRP6) mediates lipogenesis in myoblasts through AdipoR1/ERK1/2/PPAR $\gamma$ signaling pathway [80]. ERK1/2 pathway negatively regulates glycogen synthase (GS) activity in myotubes, independently of Glycogen synthase kinase 3 (GSK3) [81]. ERK1/2 are also required to phosphorylate PH domain and leucine rich repeat protein phosphatase $1 \alpha($ PHLPP1 $\alpha)$ at Ser932 under endoplasmic reticulum (ER) stress, which is required for its ability to interact with and dephosphorylate AMPK and thereby induce ER stress [82]. PHLPP1 expression is enhanced in the skeletal muscle of insulin resistant rodents that also exhibit ER stress, an important mediator of insulin resistance.

Therefore, ERK1 and ERK2 promote muscle differentiation and sustain their metabolism.

\subsubsection{The Central Role of ERK1/2 in Regulation of Appetite and Energy Dissipation}

The central nervous system (CNS) integrates signals generated by the adipose tissue-, pancreas-, and gastrointestinal-derived hormones to regulate energy homeostasis. In the CNS, insulin and leptin are the key hormones that act on hypothalamic neurons to decrease food intake and hepatic glucose production and to increase energy expenditure [83]. The hypothalamus, and particularly the arcuate nucleus (ARC), is central to the convergence of nutrient signals (e.g., glucose). ARC consists of two neuronal populations that modulate food intake and energy expenditure [84]. Neurons leading to a positive energy balance express agouti-related protein (AgRP) and neuropeptide Y (NPY), while neurons leading to a negative energy balance express proopiomelanocortin (POMC). In response to glucose, ERK1/2 regulate POMC but not AgRP/NPY expression in hypothalamic neurons [85]. Fasting activates ERK1/2 in the ARC and the paraventricular nucleus in mice [86,87] and the activation is reversed by refeeding [87]. Obesity is associated with increased protein levels of hypothalamic MAPK phosphatase-3 (MKP-3), which is related to the reduction of ERK1/2 phosphorylation in the hypothalamus as well as to an increase in body weight and a reduction in energy expenditure [88]. In parallel, leptin acts on the hypothalamus through its receptor, increasing the phosphorylation (Thr202/Tyr204) of ERK1/2 [89,90]. Mechanistically, leptin binds to the extracellular domain of the leptin receptor (LepR) dimer and activates the Jak2 tyrosine kinase. Activated Jak2 tyrosine phosphorylates itself and Tyr985 and Tyr1138 on the intracellular tail of LepR. Phosphorylated Tyr985 recruits the SH2-containing tyrosine phosphatase (SHP-2), which is itself phosphorylated and binds growth factor receptor binding 2 (Grb-2) to activate ERK1/2 signaling pathway. Inhibition of ERK1/2 reduces the ability of leptin to stimulate the sympathetic signal of the hypothalamus to brown adipose tissue, resulting in lower heat production [89]. Acute physical exercise also increases leptin-induced hypothalamic phospho-ERK1/2, associated with higher BAT UCP1 content and heat production in obese mice [91]. The increase in ERK1/2 phosphorylation is likely to depend on the intensity of the physical exercise. Therefore, physical activity promotes leptin-dependent activation of Erk1/2 in 
the hypothalamus to drive thermogenesis. Moreover, hepatocyte-secreted hormone FGF21 induces fasting gluconeogenesis via the brain-liver axis. FGF21 acts directly on the hypothalamic neurons to activate ERK1/2, thereby stimulating the expression of corticotropin-releasing hormone by activation of the transcription factor CREB [92]. In addition to the hypothalamus, the dorsal vagal complex (DVC) is an extra-hypothalamic region that integrates nutritional and hormonal signals to regulate peripheral metabolism. Insulin triggers a PI3K-independent and ERK1/2-dependent signaling cascade in the DVC to lower glucose production in healthy rodents [93]. Indeed, acute insulin infusion into the DVC activates ERK1/2 to lower food intake in healthy but not high-fat diet fed rats [94]. Direct molecular disruption of DVC ERK1/2 signaling in normal rats induces hyperphagia and obesity, whereas daily acute repeated DVC insulin infusion lowers food intake and body weight in normal rats [94]. Besides that, ERK1 also regulates feeding behaviors. Erk1 knock-out mice have been shown to exhibit low preference for dietary fat [95]. Mechanistically, in the taste bud cells ERK1/2 is activated by the opening of a specific calcium channel, calcium-homeostasis modulator-1 (CALHM1), to modulate orogustatory detection of dietary lipids in mice and humans.

All of these indicates that induction of ERK1/2 signaling in hypothalamus suppresses appetite and promotes energy expenditure in the periphery.

\subsubsection{Summary}

Different studies have shown that ERK1/2 regulate several metabolic events, and their activation is associated with deleterious effects during obesity and diabetes (Figure 1). However, several reports indicate that inactivation of ERK1/2 might promote or suppress the development of obesity and insulin resistance depending on the animal models used in the given studies [24,36,37]. Nevertheless, deletion of ERK1/2 in the liver improved systemic insulin and glucose tolerance. [22]. Interestingly, mouse primary adipocytes selectively express ERK2 [35]. Adipocyte-specific ablation of ERK2 resulted in decreased rates of lipolysis and fail to appropriately activate thermogenesis. ERK1/2 also promote adipogenesis [43,44] and determine inflammatory response during obesity [58-63]. Moreover, ERK1/2 positively regulate glucose-stimulated insulin secretion and $\beta$-cell survival $[65,66]$. Animals lacking muscle ERK1/2 displayed muscle weakness with a mixture of modest fiber atrophy and loss [77]. In hypothalamus, ERK1/2 suppress appetite and promote energy expenditure in the periphery $[89,91,94]$.

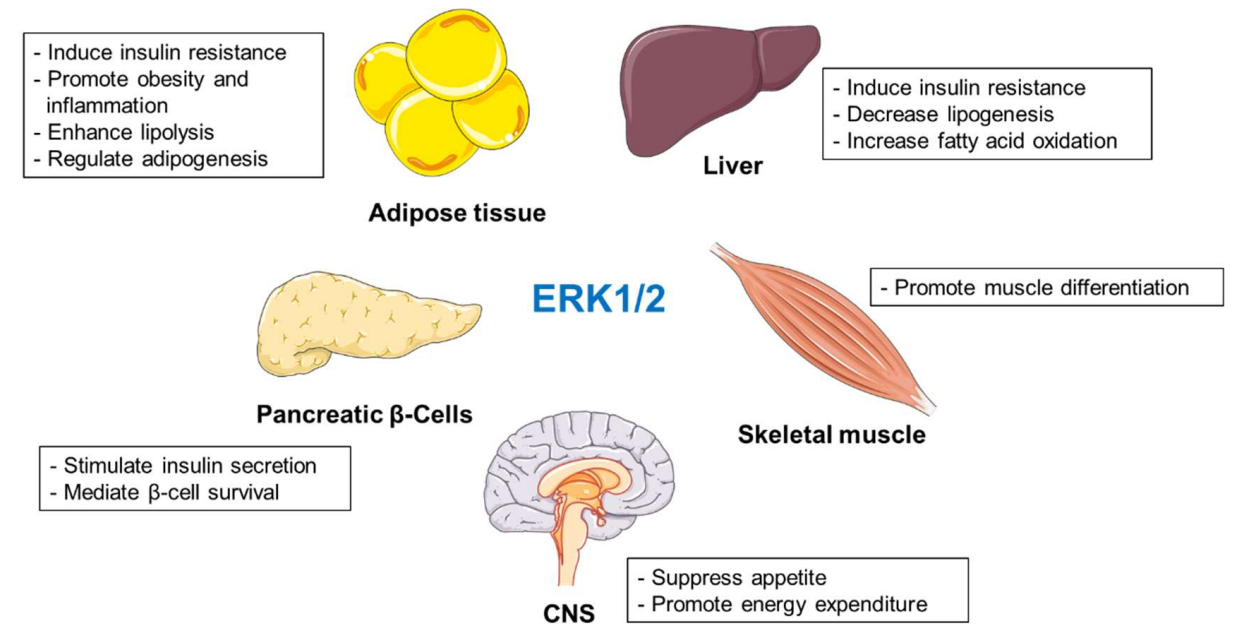

Figure 1. Roles of ERK1/2 in regulation of metabolism.

\subsection{JNK Kinases}

The cJun NH2-terminal kinase (JNK), also known as stress-activated protein kinase (SAPK), has three isoforms JNK1, JNK2, and JNK3 that are encoded by three separate genes. Whereas JNK1 and JNK2 are ubiquitously expressed in mammalian cells, JNK3 is predominantly expressed in brain, testis, and heart [96]. The JNK proteins are activated by a variety of extracellular stimuli, including 
stress (hypoxia, UV, and ionizing radiation), cytokines, growth factors, pathogens, toxins, drugs, and metabolic changes, including obesity and hyperlipidaemia. JNKs are directly activated by two upstream MAPKK enzymes, MKK4 and MKK7. Activation of JNK isoforms requires dual phosphorylation on Thr and Tyr residues within a conserved Thr-Pro-Tyr motif in their activation loops. Several enzymes, such as MEKK1 to -4, MLK1/2/3, Tpl-2, DLK, TAO1/2, TAK1, and ASK1/2, have been reported to act as MAPKKKs and consequently activate JNKs. Many substrates have been shown to be phosphorylated by JNKs (reviewed in $[2,96,97]$ ).

Through the phosphorylation of their targets (Table 1), JNKs play an important role in the control of apoptosis, cell proliferation, and cell migration [2]. JNKs phosphorylate and activate c-jun, a member of the AP-1 transcription factor family [98]. JNK1/2 promote the formation of a complex between c-jun and other members of the family of AP-1 transcription factors and thereby, mediate the transcription of AP-1 target genes involved in cell cycle and apoptosis. JNKs are known to also induce apoptosis by interacting with its substrate proteins of the outer mitochondrial membrane, including BH3-only family of $\mathrm{Bcl} 2$ proteins. [99,100]. Additionally, JNK1/2 phosphorylate other substrate proteins including p53, ATF-2, NF-ATc1, Elk-1, HSF-1, STAT3, c-Myc, and JunB [2,66].

The JNK pathway is also implicated in the regulation of obesity, T2D, insulin resistance, and atherosclerosis [4-6,101,102]. JNK activity is significantly elevated in various tissues, such as liver, muscle, and fat, in T2D patients and in diet-induced and genetic animal models of obesity and diabetes [103-106]. Mice lacking JNK1, but not JNK2, are protected against obesity and insulin resistance [103]. On the other hand, the deletion of JNK2, but not JNK1, protects from the development of atherosclerosis on in ApoE $\mathrm{E}^{-/-}$mice [102]. The JNK2 isoform is also involved in metabolic regulation, but its function is not evident when JNK1 is fully expressed due to the regulatory crosstalk between the two isoforms [107].

\subsubsection{Functions of JNKs in the Liver}

In hepatic-specific JNK-deficient mice, or in animals in which deficiency of JNK1 was induced by adenoviral delivery of shRNA [108], or mice expressing a dominant-negative JNK [109] insulin resistance evoked by HFD feeding was ameliorated. This was associated with up-regulation of the hepatic expression of clusters of genes regulating glycolysis and several genes involved in the triglyceride synthesis pathways [109]. Moreover, hepatocyte-specific double knockout of JNK1 and JNK2 induced systemic protection against HFD-induced insulin resistance [110]. These effects were associated with an upregulation of nuclear hormone receptor PPAR $\alpha$ and disruption of the hepatic PPAR $\alpha / F G F 21$ hormone axis, leading to marked increases in the rate of FA oxidation, ketogenesis, and improved hepatic insulin action. JNKs modulate liver insulin resistance mainly through insulin receptor adapter protein IRS1 phosphorylation on serine 307. Upon activation by proinflammatory cytokines (e.g., TNF $\alpha$ ) and circulating FFAs, JNKs prevent its interaction with the insulin receptor and cause insulin resistance [111]. However, mice in which Ser 307 was replaced by alanine showed reduced insulin sensitivity [112]. Interestingly, insulin stimulation itself leads to Ser 307 phosphorylation of IRS1, particularly in hepatocytes [112]. These data were supported by another report demonstrating that mice with hepatocyte-specific deletion of JNK1 displayed increased insulin resistance, glucose intolerance, and hepatic steatosis, showing that JNK1 plays a protective role in hepatocytes [113]. More recently, JNK-mediated regulation of adipokines [114] and inflammatory cytokines [115] has been implicated in the development of insulin resistance. Since the promotion of hepatic insulin sensitivity caused by JNK-deficiency in adipocytes and myeloid cells is associated with defects in adipokine/cytokine expression, it is possible that obesity-induced activation of JNK in non-hepatic cells mediates HFD-induced hepatic insulin resistance [114,115].

Overall, these findings from separate laboratories indicate that hepatic JNKs play a crucial role in the regulation of insulin sensitivity as well as glucose and lipid metabolism. 


\subsubsection{JNKs Promote Inflammatory Mediators in Adipose Tissue}

Deletion of JNK1 specifically in adipocytes improved adipose tissue insulin action and suppressed liver insulin resistance induced by high-fat diet feeding [114]. Improvement in hepatic insulin sensitivity evoked by deletion of JNK1 in adipocytes was associated with a reduction in the expression of the inflammatory cytokine IL-6 secreted by adipose tissue, and the expression of the classical IL-6 target gene, suppressor of cytokine signaling 3 (SOCS3), in the liver. SOCS3 has previously been linked to the development of hepatic insulin resistance [116]. Similarly to ERK1/2, the activation of TNF $\alpha$ leads to increased basal lipolysis due to the downregulation of perilipin mRNA and protein [39]. Moreover, high mobility group box 1 (HMGB1), a pro-inflammatory adipocytokine involved in WAT inflammation and insulin resistance in patients with obesity was secreted by adipocytes in response to JNK signaling [117]. Furthermore, the scaffold protein JNK interacting protein 1 (JIP1) has been shown to play a central and cell-specific role in JNK activation in the adipose tissue. Mice lacking JIP1 are protected from diet-induced obesity and show less severe insulin resistance. JNK cannot be activated in the adipose tissue and muscle of these mice, preventing them from the development of insulin resistance in both organs. However, livers of these animals have no defect in JNK activation [118]. Finally, blocking JNK activation prevented cold-induced subcutaneous WAT beiging [119]. ERK 1/2 and JNK were both activated in beige adipocytes under ER stress conditions and regulated the mRNA levels of UCP1 involved in thermoregulation and PPAR $\gamma$, which is known as a UCP1 transcriptional activator [120]. Interestingly, only JNK inhibition, but not ERK, rescued the PPAR $\gamma$ protein.

In summary, JNKs promote insulin resistance, inflammation, and beige adipocytes in adipose tissue.

\subsubsection{The role of JNKs in Immune Cells}

Early studies indicate that JNKs may also be involved in obesity-induced inflammation [107]. Reciprocal adoptive transfer experiments demonstrated that JNK1 deletion in non-hematopoietic tissues protects against weight gain and, partly as a consequence, from insulin resistance [121]. On the other hand, hematopoietic JNK1 removal reduces obesity-induced inflammation and protects against HFD-induced insulin resistance without affecting obesity [121]. However, another study indicated that JNK1-deficient bone marrow transplantation was insufficient to affect macrophage infiltration or insulin sensitivity despite minimal changes in the inflammatory profile of adipose tissue, whereas this protection was induced by the absence of JNK1 in parenchymal cells [122]. Importantly, HFD-fed mice overexpressing dominant-negative JNK in adipose tissue and macrophages showed reduced weight gain, insulin resistance, glucose intolerance, and hepatic steatosis. These mice had smaller than normal adipocytes, reduced macrophage infiltration in adipose tissue, and less severe whole-body inflammation, highlighting an important role for JNK in the crosstalk between adipose tissue and macrophage infiltration [123]. Indeed, the combined loss of both JNK1 and JNK2 from macrophages results in a significant protection from obesity-induced impairments to glucose metabolism and the development of insulin resistance but has no effect on HFD-induced obesity [115]. The myeloid JNK1/2-knockout mice also show less macrophage infiltration and decreased M1 polarization in adipose tissue. M1 polarization was also decreased in hepatic macrophages, accompanied by increased M2 polarization, highlighting an important role for JNKs in M1 polarization. Macrophages polarization to the M1, pro-inflammatory state leads to enhanced production of pro-inflammatory factors such as IL- $1 \beta, T N F \alpha$, and IL- 6 . Thus, in the context of a HFD, pro-inflammatory cytokines within the adipose tissue are likely to contribute to elevated lipolysis by directly initiating it, and by impairing insulin ability to suppress it [124]. The consequence of this inflammation-dependent increase in adipose tissue lipolysis is elevated hepatic acetyl-CoA content, which allosterically activates pyruvate carboxylase, leading to the generation of oxaloacetate and subsequent conversion to glucose. Remarkably, in mice fed a HFD, the deletion of JNK from macrophages reduces hepatic acetyl-CoA content, pyruvate carboxylase activity and dramatically improves the ability of insulin to suppress hepatic glucose production [124]. These data clearly associate inflammation in adipocyte tissue to both fasting and postprandial hyperglycemia in T2D. Finally, non-obese diabetic mice lacking JNK2 exhibit a decrease 
in destructive insulitis and a reduced disease progression to diabetes, probably due to increased Th2 polarization of CD4+ T cells [125]. This study reported that T-cell polarization effect was not seen in JNK1 ${ }^{-/-}$mice, indicating a specific role for JNK2 in the regulation of T-cell polarization in type 1 diabetes [125].

Taken together, JNK1/2-mediated signaling in immune cells promotes inflammation, which then mediates peripheral insulin resistance as well as pancreatic $\beta$-cell death.

\subsubsection{The Impact of JNKs on Pancreatic $\beta$-Cells during Type 1 and Type 2 Diabetes}

Different studies have demonstrated that inhibition of JNKs prevents $\beta$-cell dysfunction and apoptosis in human islets and in $\beta$-cell lines [126-129]. Indeed, in a selective in vivo model of $\beta$-cell dysfunction, inhibition of JNK using either JNK inhibitor or JNK1-null mice preserves $\beta$-cell function during hyperglycemic clamps [130]. Mechanistically, chronically elevated concentrations of leptin and glucose induce $\beta$-cell apoptosis through the activation of the JNK pathway [128]. Type I and II interferons (IFNs) production may interact with protein tyrosine phosphatase non-receptor 2 (PTPN2) to induce aberrant proapoptotic activity of the $\mathrm{BH} 3$-only protein Bim, leading to an increased $\beta$-cell apoptosis via JNK activation and the intrinsic apoptotic pathway. JNK1/2 mediates IL-1 $\beta$-induced ER $\mathrm{Ca}^{2+}$ release and the consequent mitochondrial dysfunction in mouse and primary human pancreatic $\beta$-cells [131]. Oxidative stress-induced activation of JNK impairs insulin signaling cascade [132] and thus activates FOXO-1, resulting in decreased expression and nuclear localization of pancreatic and duodenal homeobox $1(\mathrm{Pdx}-1)$ with consequent reduction of insulin gene transcription. Finally, JIP1 has been also shown to mediate $\beta$-cell apoptosis [133]. However, studies in animals lacking JIP1/JIP2 proteins indicate that these proteins are not essential for $\beta$-cell viability [134]. Importantly, several studies have proposed that JNK isoforms exhibit differential roles in $\beta$-cell apoptosis depending on the stimuli. JNK3 was found to have antiapoptotic properties in cytokine-induced $\beta$-cell apoptosis, whereas JNK1 and JNK2 were reported to serve proapoptotic functions in response to cytokines [135]. JNK1, however, exerts an antiapoptotic function in palmitate- and high glucose-induced $\beta$-cell death [136]. JNK2 knockdown did not influence palmitate- and high glucose-induced $\beta$-cell apoptosis, and JNK3 knockdown only increased cleaved caspase 9 and 3 but not apoptosis [136]. In addition, FFA stimulates autophagy in $\beta$-cells via JNK1 signaling pathways independently of oxidative or ER stress, and JNK2 $2^{-/} \beta$-cells in non-obese mice are protected against apoptosis induced by $\mathrm{T}$ cells in a model of autoimmune type 1 diabetes [125].

Therefore, specific members of JNK family differentially regulate pancreatic $\beta$-cell apoptosis depending on the stimuli.

\subsubsection{JNKs in Skeletal Muscle Metabolism}

Similar to other tissues, JNK1 is activated in muscle from HFD-fed mice and, therefore, may potentially impact skeletal muscle glucose metabolism [103]. Early studies showed that overexpression of a constitutively active (CA) JNK, but not WT JNK, in the tibialis anterior muscle of mice led to a reduction in insulin-stimulated glucose clearance [137]. However, no effect of skeletal muscle-specific CA JNK on the development of obesity, glucose tolerance, or insulin sensitivity could be observed [138]. Moreover, inhibiting JNK in muscle by overexpressing heat shock protein 72 (HSP72) improved HFD-induced hyperglycaemia and hyperlipidaemia [104]. Furthermore, it prevented glucose intolerance and insulin resistance and reduced HFD-induced weight gain. However, skeletal muscle-specific deletion of JNK1 did not affect the development of HFD-induced obesity [138,139]. Yet, these mice were protected against obesity-induced insulin resistance and showed increased glucose uptake by muscle. Additionally, adipose tissue and liver were not positively affected by JNK1 deficiency in skeletal muscle. Instead, these mice showed increased hepatic steatosis and circulating levels of triglycerides and increased adipose tissue macrophage infiltration [139]. In contrast, no effect of skeletal muscle-specific JNK1 deletion on any indices of glucose metabolism or insulin sensitivity was observed in a similar study using the same in vivo model [138]. Finally, ER stress induced by 
palmitate could increase the expression of hepassocin (HPS) in hepatocytes and further contribute to the development of insulin resistance in skeletal muscle via EGFR/JNK-mediated pathway [140].

Therefore, JNK-mediated signaling in muscle likely attenuates glucose uptake in this tissue but has a minor effect on the whole-body insulin sensitivity.

\subsubsection{Central Regulation of Metabolism by JNKs}

JNKs activity was significantly elevated in the hypothalamus $[83,141]$ and pituitary gland [83] in obese mice. In CNS/pituitary-specific JNK1 knockout mice, a reduced body-weight gain was observed and correlated with an increased energy expenditure and locomotor activity and a higher body temperature $[83,142]$. These mice were protected against insulin resistance and glucose intolerance at the central and peripheral levels. Moreover, they displayed activation of the hypothalamus-pituitary-thyroid axis, as indicated by increased circulating thyroid-stimulating hormone (TSH), T3, and T4 levels, as well as increased expression of TSH $\beta$ and the thyroid releasing hormone receptor (TRHR) within the pituitary gland. Collectively, these data indicate a major role of JNK1 in the control body homeostasis by regulating the pituitary-thyroid axis $[83,142]$. These observations were supported by another report showing that pituitary-specific deletion of JNK1 and JNK2 largely prevented HFD-induced obesity [143]. These mice have elevated circulating levels of T3, T4, and TSH. In fact, JNK1/2 regulate expression of type 2 iodothyronine deiodinase (Dio2), which encodes the enzyme responsible for T4 to T3 conversion in the pituitary gland. Impairment of this conversion reduces the negative feedback regulation of the expression of TSH, resulting in sustained production of TSH, T3, and T4 [143]. In contrast, mice expressing constitutively active JNK1 in AgRP-expressing neurons become more obese and are more leptin resistant at the neuronal and systemic levels than control animals when fed a HFD [141]. Indeed, AgRP-specific deletion of p53 resulted in increased hypothalamic JNK activity before the mice developed obesity, and central inhibition of JNK reversed the obese phenotype of these mice [144]. Mechanistically, T3 regulates hepatic lipogenic pathway by increasing AMPK-induced JNK1 activity specifically in the ventromedial nucleus of the hypothalamus (VMH), leading to hepatic vagal activation [145].

Overall, hypothalamic activation of JNK pathway promotes obesity and diabetes.

\subsubsection{Summary}

JNKs are central kinases regulating metabolism in multiple organs (Figure 2). Mice lacking JNK1, but not JNK2, are protected against obesity and insulin resistance [103]. JNK2 is also involved in metabolic regulation, but its function is not evident when JNK1 is fully expressed. [107]. Findings from separated laboratories present an ambiguous picture of the role of hepatic JNKs in regulation of metabolism [108-113]. However, JNK-deficiency in non-hepatic cells (adipocytes and myeloid cells) promotes insulin sensitivity $[114,115]$. Deletion of JNK1 specifically in adipocytes improved adipose tissue insulin action but prevented cold-induced subcutaneous WAT beiging [114,119]. Moreover, JNK1/2-mediated signaling promotes inflammation [107,115,121-125]. Additionally, JNK isoforms present differential roles in pancreatic $\beta$-cell, promoting or suppressing apoptosis depending on the stimuli $[135,136]$. Different contradictory results do not fully elucidate the role of JNK proteins expressed in skeletal muscle [104,137-139]. Finally, JNK activation in hypothalamus contributes to the development of obesity and diabetes [83,142].

\section{3. p38 Kinases}

There are four members of the p38 MAPKs family (p38 $\alpha, \beta, \gamma$, and $\delta$ ) encoded by four different genes that have different tissue expression patterns. p38 isoforms are expressed differently in individual cells and have varied and often opposite effects even within the same cell on the same substrate [2,6]. p38 isoforms are strongly activated by various environmental stresses including oxidative stress, UV irradiation, hypoxia, ischemia, inflammatory cytokines, GPCRs, and Rho family GTPases. In addition to the usual activation by two upstream MAPKKs, MKK3 and MKK6, the p38 
MAPKs can also be activated by binding of TAB1 or phosphorylation by the tyrosine kinases ZAP70 and LCK. MKK3/6 are activated by several MAPKKKs, including MEKK1 to -3, MLK2/3, ASK1, Tpl-2, TAK1, and TAO1/2 [2]. All p38 isoforms are activated in response to appropriate stimuli by dual phosphorylation in the activation loop sequence Thr-Gly-Tyr.

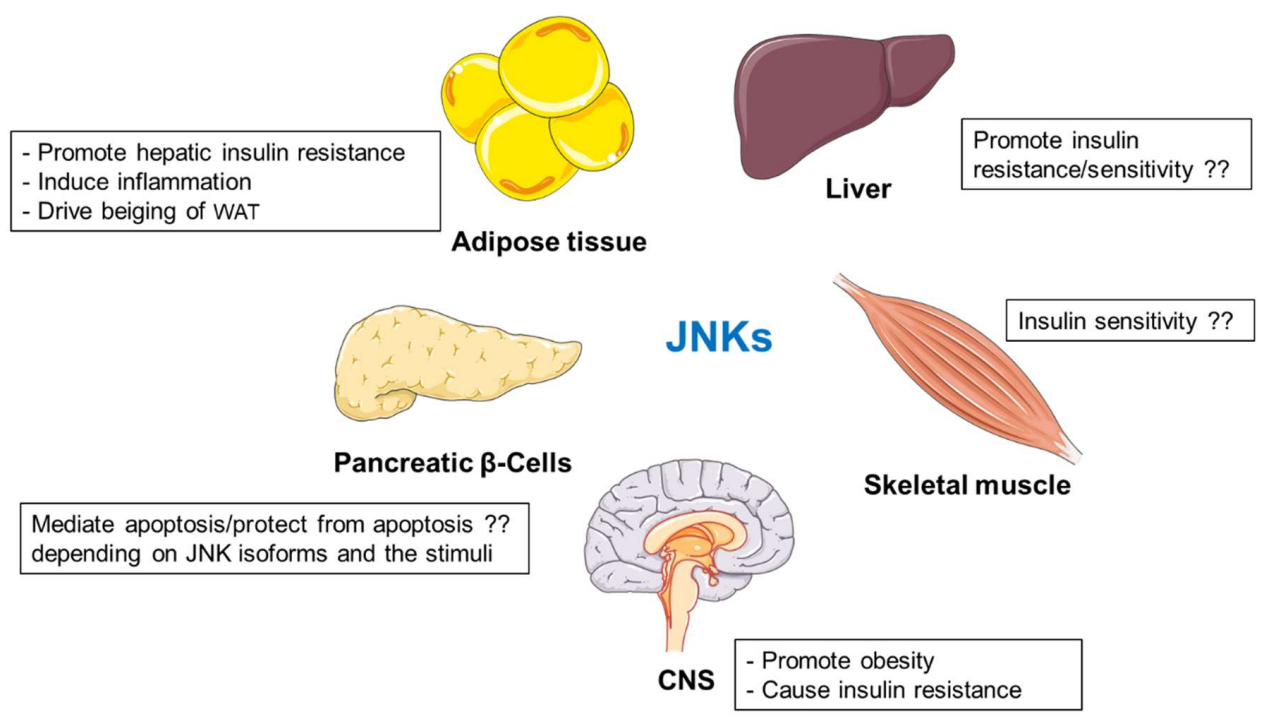

Figure 2. The role of JNKs in various tissues and organs.

p38 MAPKs play critical roles in a wide variety of cellular processes such as proliferation, differentiation, regeneration, and metabolism [2]. Upon stimulation, p38 isoforms phosphorylate a large number of substrates in many cellular compartments (Table 1) (reviewed in [2,146]). Similarly, to ERK1/2, p38s are known to interact and phosphorylate MSKs and MNK1/2 [10,11]. These kinases are involved in multiple biological functions including cell differentiation, cytokine production, cell cycle regulation, and apoptosis $[10,11]$. Furthermore, p38s are also known to phosphorylate transcription factors including ATF, Elk-1, and p53 [66]. P38 MAPKs phosphorylate and stabilize p53 by preventing its MDM2-induced proteasomal degradation, resulting in its nuclear accumulation and the transcription activation of its apoptotic target genes $[147,148]$. On the other hand, p38s-ATF axis was shown to regulate ER stress response $[149,150]$. Additionally, p38s are involved in inflammatory responses by interacting with nuclear transcription factors such as ATF-2 and NF- $\mathrm{kB}$, resulting in the expression of inflammatory cytokines [151].

p38 $\alpha$, which is by far the best-characterized member of the p38 family, is known to phosphorylate several key proteins involved in glucose and lipid metabolism [6]. As most commonly used p38 inhibitors (SB203580 and SB202190) targets only p38 $\alpha$ and $\beta$ isoforms [152], relatively less is known about $\mathrm{p} 38 \gamma$ and $\delta$ isoforms. However, many studies suggest that $\mathrm{p} 38 \mathrm{~s}$ regulate the metabolism of different cell types and are central in the pathogenesis of metabolic diseases.

\subsubsection{The Role of $\mathrm{p} 38 \mathrm{~s}$ in the Liver}

Hepatic p38 is a pivotal regulator of hepatic gluconeogenesis. It has been shown that liver expression of dominant-negative p38 $\alpha$ in obese mice reduced fasting insulin levels and improved glucose tolerance [153]. In response to different stress stimuli, p38 $\alpha$ activation initiates ErbB receptors (epidermal growth factor EGF/ErbB family of receptor Tyr-kinases) signaling, leading to Ser phosphorylation of IRS1 proteins which impair cellular response to insulin [153]. Indeed, mice lacking hepatic p38 $\alpha$ exhibited reduced fasting glucose levels and impaired gluconeogenesis [154]. In addition, an elevated liver expression of p38 8 was detected in a cohort of obese patients with NAFLD, and p38 $\gamma$ and p38 were found to be responsible for the development of steatosis in different mouse models of NAFLD [155]. p38 $\alpha$ stimulates hepatic gluconeogenesis by regulating the phosphorylation 
of CREB and the expression of PGC- $1 \alpha$ [156]. PGC- $1 \alpha$ has been identified as a direct target of p38 $\alpha / \beta$ [157]. PGC- $1 \alpha$ also co-activates many other transcription factors, including the glucocorticoid receptor, FOXO1, and PPAR $\alpha$. Phosphorylation of the glucocorticoid receptor by $p 38 \alpha / \beta$ seems to enhance its transcriptional activity [158], whereas phosphorylation by JNKs and ERK1/2 inhibits its function $[159,160]$. The transcriptional activity of PPAR $\alpha$ is also enhanced by phosphorylation by ERK1/2 and $p 38 \alpha / \beta$ [161]. Moreover, CREB is a direct target of MSK that is activated by ERK1/2 and $\mathrm{p} 38 \alpha / \beta$ [162]. However, hepatic deficiency of $\mathrm{p} 38 \alpha$ in vivo did not result in an alteration in CREB phosphorylation, suggesting that $\mathrm{p} 38 \alpha$ signaling might not be required for the activation of CREB during fasting [154]. Furthermore, $p 38 \alpha / \beta$ phosphorylate CCAAT-enhancer-binding protein- $\alpha$ $(\mathrm{C} / \mathrm{EBP} \alpha)$ [163], a transcription factor that regulates hepatic gluconeogenesis [164]. Phosphorylation on serine 21 enhances $\mathrm{C} / \mathrm{EBP} \alpha$ transactivation activity and increases phosphoenolpyruvate carboxykinase kinase (PEPCK), a gluconeogenic gene, expression [163]. p38 $\alpha / \beta$ also phosphorylate the spliced form of X-box binding protein 1 (Xbp1s), promoting its nuclear translocation, reducing ER stress, and improving glycemia during obesity [165]. Moreover, $p 38 \alpha / \beta$ were shown to be required for glucagon and fasting-mediated suppression of hepatic lipogenesis, possibly through the inhibition of central lipogenic genes transcription, sterol regulatory element-binding protein 1 (SREBP1) and PGC-1 $\beta$ [166]. A more recent study showed that DUSP12, which plays an important role in brown adipocyte differentiation, physically binds to ASK1, promotes its dephosphorylation, and inhibits its action on $p 38 \alpha / \beta$ in order to reducelipogenesis and to suppress lipid accumulation in livers of high-fat fed mice [167]. Similar to DUSP12, DUSP14, DUSP26 and MKP-5 suppress the development of hepatic steatosis by inhibiting p38s [167-170]. Both DUSP14 and DUSP26 directly bind and dephosphorylate TAK1 kinase, which results in the inhibition of TAK1 and its downstream targets JNKs and p38s [168,169]. MKP-5 prevents the development of hepatic steatosis by suppressing p38-ATF2 and p38-PPAR $\gamma$ signaling axis to reduce hepatic lipid accumulation [170]. Finally, F-prostanoid receptor (FP) activation through the CaMKII $\gamma / \mathrm{p} 38 / \mathrm{FOXO} 1$ signaling pathway was demonstrated to facilitate hepatic gluconeogenesis in mice by upregulating gluconeogenic genes under both fasting and diabetic conditions [171]. FP activation promoted FOXO1 nuclear translocation by stimulating CaMKII $\gamma$ signaling, and p38 was required for this translocation.

Taken together, members of $\mathrm{p} 38$ family promote hepatic insulin resistance and gluconeogenesis but suppress lipogenesis in liver.

\subsubsection{Functions of p38s in Adipose Tissue}

p38s have long been known as a central mediator of cAMP/PKA signaling, which positively regulate the transcription of $\mathrm{UCP} 1$ in brown adipocytes [172]. Besides, the $\mathrm{p} 38 \alpha / \beta$ downstream target activating transcription factor 2 (ATF2) induces the expression of PGC- $1 \alpha$, and these two nuclear transcription factors together control the expression of UCP1 [172]. In WAT, the activation of p38 $\alpha$ could also be mediated by the alternative mechanism involving AMPK, TAK, and TAB [173]. Similarly, bone morphogenetic protein 7 (BMP7) is able to activate a full program of brown adipogenesis, including UCP1, via p38 $\alpha / \beta$-dependent pathways [174]. Additionally, irisin, a hormone secreted by skeletal muscles, promotes WAT browning by stimulating expression of WAT browning-specific genes via the $\mathrm{p} 38 \alpha / \beta$ and ERK1/2 pathways [175]. Surprisingly, adipocyte-specific deletion of $\mathrm{p} 38 \alpha$ caused minimal effects on BAT in adult mice, as evident from undetectable changes in UCP1 expression, mitochondrial function, body temperature, and energy expenditure [176]. On the other hand, genetic ablation of p38 $\alpha$ in adipose tissues not only significantly facilitates the browning in WAT upon cold stress, but also prevents diet-induced obesity [176]. Mechanistically, inhibition of p38 $\alpha$ stimulates the UCP1 transcription through PKA and its downstream target CREB [176]. However, these observations are in contradiction with a recently published study using the same in vivo model, and showing that adipocyte-specific p38 $\alpha$ knockout mice were protected against HFD-induced obesity, had increased energy expenditure and a higher BAT thermogenesis [177]. Lack of p38 $\alpha$ in BAT resulted in higher activation of $\mathrm{p} 38 \delta$, suggesting that $\mathrm{p} 38 \alpha$ controls $\mathrm{p} 38 \delta$ activity, thereby regulating thermogenesis and 
energy homeostasis. In contrast, in WAT, p38 $\alpha$ would have opposite effects depending on the fat depots, blocking browning through inhibition of p38 $\gamma$ in inguinal fat (iWAT) [177], and promoting browning in epididymal fat (eWAT) [173]. Moreover, $\beta 3$-adrenergic-induced p38 and JNK pathways promote hormone-sensitive lipase (HSL)-mediated lipolysis. At the same time, $p 38 \alpha / \beta$ and JNKs mediate pro-inflammatory cytokines expression in adipose tissue [178]. Finally, it has been proposed that $\mathrm{p} 38 \alpha / \beta$ promote adipogenesis through the phosphorylation of C/EBP $\beta$ [179], a key transcription factor for adipose tissue differentiation [180]. Experiments with p38 inhibitors and p38 $\alpha$ knockout cells have shown that $\mathrm{p} 38$ phosphorylates and activates $C / E B P \beta$, leading to adipogenesis via PPAR $\gamma$ upregulation [181]. However, lack of $\mathrm{p} 38 \alpha$ in preadipocytes did not affect their differentiation to adipocytes, nor did it affect changes in the differentiation markers evaluated in the major fat depots [177].

Therefore, specific members of p38 family differentially regulate adipose tissue metabolism.

\subsubsection{The Role of p38s in Pancreatic $\beta$-Cells}

Several reports suggest that activation of the p38s pathway promotes $\beta$-cell apoptosis and that p38s activity is increased in pancreatic islets of T2D model mice [182]. Indeed, p38 inhibitor SB203580, which targets p38 $\alpha$ and p38 $\beta$, but not other members of the family, can lower blood glucose by improving $\beta$-cell function mediated through a reduction in $\beta$-cell apoptosis [183]. Additionally, the inhibition of $\mathrm{p} 38$ (both $\mathrm{p} 38 \alpha$ and $\mathrm{p} 38 \beta$ ) or JNKs activity increased paired box 6 (Pax6) levels in high glucose-treated $\beta$-cells. Pax6 is known to be a key transcription factor playing pivotal roles in $\beta$-cell function, including cell survival, insulin biosynthesis, and secretion [184]. Mechanistically, calcium-independent phospholipase A2 $\beta$ (iPLA2 $\beta$ ), downstream target of p38, seems to be involved in islet $\beta$-cell apoptosis [185]. Moreover, ER stress-induced ASK1/p38 activation similarly induced pancreatic $\beta$-cell death [182]. However, this involvement of $\mathrm{p} 38 \alpha / \beta$ does not seem to play a key role in apoptosis [65]. It has also been shown that activated $\mathrm{p} 38 \alpha / \beta$ MAPK probably inhibits the ERK pathway [65].

Different studies have suggested that $\mathrm{p} 38$ isoforms may present various functions for $\beta$-cells. For instance, p388 controls insulin secretion through the phosphorylation and inhibition of PKD1 [186]. In the absence of p388, activity of PKD1 is enhanced, which promotes trans-Golgi network function dynamics and consequently stimulates insulin secretion. Consistently, mice lacking p38 present elevated insulin levels and are protected against diabetes. Interestingly, stress-induced $\beta$-cell death is also prevented by the deletion of p388 [186]. Of note, p388-PKD1 axis also regulates autophagy and lysosomal degradation of insulin nascent granules in $\beta$-cells, which allow appropriate response to the nutrient availability and maintain the secretory function of $\beta$-cells [187]. However, the exact molecular mechanisms by which the p38ס-PDK1 pathway is regulated remain to be defined. Furthermore, p38 $\alpha$ directly affects the glucose uptake in pancreatic $\beta$-cells through TSH signaling by up-regulating the expression of GLUT2 gene [188]. Finally, p38 $\gamma$ may have an important role in TNF $\alpha$-mediated downregulation of ATP-binding cassette transporter A1 (ABCA1) expression, leading to suppression of insulin secretion [189].

To sum up, distinct $\mathrm{p} 38$ members promote pancreatic $\beta$-cell death and suppress insulin secretion.

\subsection{4. p38s Define Inflammatory Response to Control Metabolism}

The p38 MAPK family regulates several cytokines levels and therefore controls systemic inflammation. Inhibition of p38, either by inhibitors (targeting p38 $\alpha$ and p38 $\beta$ ) or negative dominance, leads to reduced IFN- $\gamma$ production by T helper Th1 cells but does not affect IL-4 production by Th2 cells $[190,191]$. Suppression of the p38 pathway significantly suppressed the release of TNF $\alpha$ and prostaglandin E2 (PGE2) from macrophages and inhibited cyclooxygenase-2 (COX-2) expression [192]. Macrophage deletion of $\mathrm{p} 38 \alpha$ impairs the innate immune response, indicating that $\mathrm{p} 38 \alpha$ activation is important for cytokine production (TNF $\alpha, \mathrm{IL}-12$, and IL-18), as well as for the activation of transcription factors C/EBP- $\beta$ and CREB [193]. In parallel, myeloid-specific p38 $\gamma$ and $p 38 \delta$ gene ablation impaired cytokine production of TNF $\alpha$, IL-1 $\beta$, and IL-10 by blocking ERK1/2 protein kinase pathway activation 
in macrophages and in dendritic cells [194]. Translational elongation of nascent pro-TNF $\alpha$ protein is mediated by eukaryotic elongation factor 2 (eEF2) kinase, which is inhibited by p38 $\gamma / \mathrm{p} 38 \delta$-mediated phosphorylation [195]. The lack of p38 $\gamma$ and p38 in myeloid cells also impaired the migration of neutrophils to the liver and thus protected against steatosis and further hepatic damage [155]. The low adhesion and higher rolling velocity observed in neutrophils lacking p38 $\gamma$ and p38 $\delta$ were strongly similar to previous reports using global and myeloid-specific deletion of p38 in mice [196]. Neutrophils have been shown to be important mediators of alcoholic fatty liver disease [197], and p38 is known to regulate the neutrophil inflammatory response in the lungs by controlling PKD1 activity [196].

Therefore, p38 members might control metabolism also by regulation of immune responses.

\subsection{5. $\mathrm{p} 38 \mathrm{~s}$ in Regulation of Skeletal Muscle Function}

Increased activation of p38 MAPK has been observed in skeletal muscle from T2D patients [198]. Indeed, p38 activation was found to be increased in the diabetic myotubes, and $p 38 \alpha / \beta$ kinases were identified as a key regulator of the expression of different proinflammatory genes associated with an upregulated gene sets in diabetic myotubes [199]. However, $p 38 \alpha / \beta$ inhibition in diabetic skeletal muscle cells did not improve the retained defect of insulin-stimulated glucose uptake despite decreased inflammatory cytokine expression [199]. Thus, increased infiltration of proinflammatory macrophages could contribute to the reduced myoblast differentiation, associated with obesity-induced muscle loss by secreting the inflammatory cytokine TNF $\alpha$ via p38 signaling pathway [200]. As previously mentioned, increased infiltration of proinflammatory macrophages in skeletal muscles is noted in obesity and is associated with muscle insulin resistance. Importantly, cachectic cancer cells have been found to secrete many inflammatory factors that have rapidly led to high levels of FA metabolism and to the activation of a p38 stress-response signature in skeletal muscles, before the manifestation of cachectic muscle atrophy occurred [201]. These secreted factors rapidly induce excessive FA oxidation in human myotubes, which leads to oxidative stress, p38 activation, and impaired muscle growth. Moreover, FA binding protein 4 (FABP4) inhibitor reduces FA-induced ER stress-associated inflammation in skeletal muscles by reducing p38 MAPK activation [202]. Additionally, angiotensin II induces insulin resistance in skeletal muscle by a mechanism dependent on oxidative stress and activation of $\mathrm{p} 38$, which results in decreased function of glucose transporter type 4 [203]. On the other hand, the deletion of MKP-1, which results in the activation of $\mathrm{p} 38 \mathrm{~s}$ and JNKs, leads to increased oxidative metabolism in muscles and elevated energy expenditure in mice and thus prevents obesity and insulin resistance [204].

Several reports suggest that p38 isoforms could present different metabolic functions in skeletal muscle cells. The $\alpha$ isoform positively regulates muscle atrophy [205], whereas the $\gamma$ isoform regulates endurance exercise-induced mitochondrial biogenesis and angiogenesis [206] and glucose uptake [207]. p38 $\gamma$ is also involved in muscle-specific exercise-induced skeletal muscle adaptation, and it seems to be required for the upregulation of PGC- $1 \alpha$ in mitochondrial biogenesis and angiogenesis in response to exercise and nerve stimulation in mice. In addition, $\mathrm{p} 38 \gamma$ improves basal glucose uptake and lowers contraction-stimulated glucose uptake, partially by affecting levels of glucose transporter 4 expression in skeletal muscle [207]. On the contrary, the $\beta$ isoform appears to be responsible for the catabolic effect of p38 MAPK because it activates the transcription factor C/EBP $\beta$ that up-regulates atrogin1 [208]. Indeed, activation of type IIB activin receptor (ActRIIB) by activin A induces muscle catabolism, primarily through the activation of p38 $\beta$-mediated catabolic signaling that activates ubiquitin-proteasome and autophagy-lysosome pathways [209].

To sum up, members of p38 family play a central role in the regulation of skeletal muscle metabolism and are implicated in the development of metabolic diseases.

\subsection{6. p38s in Central Regulation of Metabolic Homeostasis}

Similarly to ERK1/2, fasting activates p38s in the ARC and paraventricular nucleus in mice [86,87], and this activation is reversed by refeeding [87]. Fasting also regulates F $f 21$ production in tanacytes via p38 $\alpha / \beta$ kinase [210]. Tanycytes, the hypothalamic ependymo-glia, sense FFA to maintain body lipid 
homeostasis through Fgf21 signaling within the hypothalamus. In fact, tanycytes store palmitate in lipid droplets and oxidize it, leading to the activation of a ROS/p38 signaling pathway, which is essential for tanycytic Fgf21 production upon palmitate exposure. In parallel, in diabetic untreated rats presenting hyperglycemia, p38s activity showed significant alterations in striatum, hippocampus, hypothalamus and pons medulla that correlated with the changes of levels of both catecholamines, dopamine, and epinephrine [211]. These changes were reversed in insulin-treated diabetic rats, suggesting that p38s may regulate the rate of either the synthesis or release of dopamine and epinephrine in the corresponding brain areas. Moreover, p38s seems also to be implicated in different signaling pathways regulating insulin-sensitive tissues within the hypothalamus. Nuclear factor of activated T cells 3 (NFATc3)-knockout markedly attenuated HFD-triggered insulin resistance, liver steatosis, and importantly neuroinflammation and apoptosis, which was attributed to the reduced activation of p38s/JNKs signaling pathways [212]. Interestingly, p38s or JNKs activation could rescue inflammatory response and apoptosis in NFATc3-KO astrocytes. In the same context, resistin, a polypeptide secreted by adipose tissue in rodents and by macrophages in human, promoted the activation of p38s and JNKs, enhanced serine phosphorylation of IRS1, and increased the expression of the pro-inflammatory cytokine IL-6 in the hypothalamus and key peripheral insulin-sensitive tissues [213].

To sum up, p38 activation in the hypothalamus determines peripheral metabolism.

\subsubsection{Summary}

Several studies place p38s as important regulators of metabolic homeostasis (Figure 3). Mice lacking hepatic p38 $\alpha$ exhibited reduced fasting glucose levels and impaired gluconeogenesis [154]. p38 $\alpha / \beta$ were also shown to be required for glucagon and fasting-mediated suppression of hepatic lipogenesis [166]. Interestingly, p38 $\gamma$ and p38 are responsible for the development of liver steatosis [155]. In adipocytes, specific members of p38 family differentially regulate adipose tissue metabolism [173,176,177]. Findings from different laboratories present an ambiguous picture of the role of $\mathrm{p} 38 \alpha$ in browning and thermogenesis $[173,176,177]$. Similar to adipocytes, p38 isoforms present various functions in pancreatic $\beta$-cells and skeletal muscle $[186-189,207,208]$. In pancreatic $\beta$-cells, $p 38 \delta / \gamma$ suppress insulin secretion $[186,187,189]$, whereas p38 $\alpha$ promotes glucose uptake [188]. In skeletal muscle cells, p38 $\gamma$ stimulates glucose uptake [207]. On the contrary, the $\beta$ isoform appears to be responsible for the catabolic effect [208]. Finally, p38 activation in the hypothalamus seems to maintain body lipid homeostasis [210] and to regulate insulin-sensitivity in peripheral tissues as well as pro-inflammatory cytokine expression [212,213].

\subsection{ERK5 Kinase}

ERK5, also termed big mitogen-activated protein kinase-1 (BMK1), is the most recently identified member of the conventional MAPK family [214]. ERK5 is activated by different extracellular stimuli, including growth factors, inflammatory cytokines, oxidative and osmotic stresses, ischaemia, and hypoxia. The MAPKKKs activated by these extracellular stimuli are MEKK2 and MEKK3, which specifically phosphorylate the MAPKK MEK5, which in turn, directly activates ERK5 through phosphorylation of both tyrosine and threonine residues of the Thr-Glu-Tyr motif present within the activation loop of the ERK5 kinase domain. Because of its unique extended C-terminus containing a nuclear localization signal, two proline-rich regions, and a transcriptional activation domain, it appears that the most significant role of ERK5 is to regulate a number of downstream transcription factors. A variety of downstream substrates, including other kinases such as serum- and glucocorticoid-induced protein kinase (SGK) and transcription factors such as MEF2, Elk-1 and Sap1a are phosphorylated by ERK5 [214] (Table 1). Although it is associated with a diverse range of cellular processes including cellular proliferation, migration, survival, and angiogenesis, little is known regarding the importance of ERK5 in metabolism regulation and energy homeostasis (reviewed in [1,2,214]). 


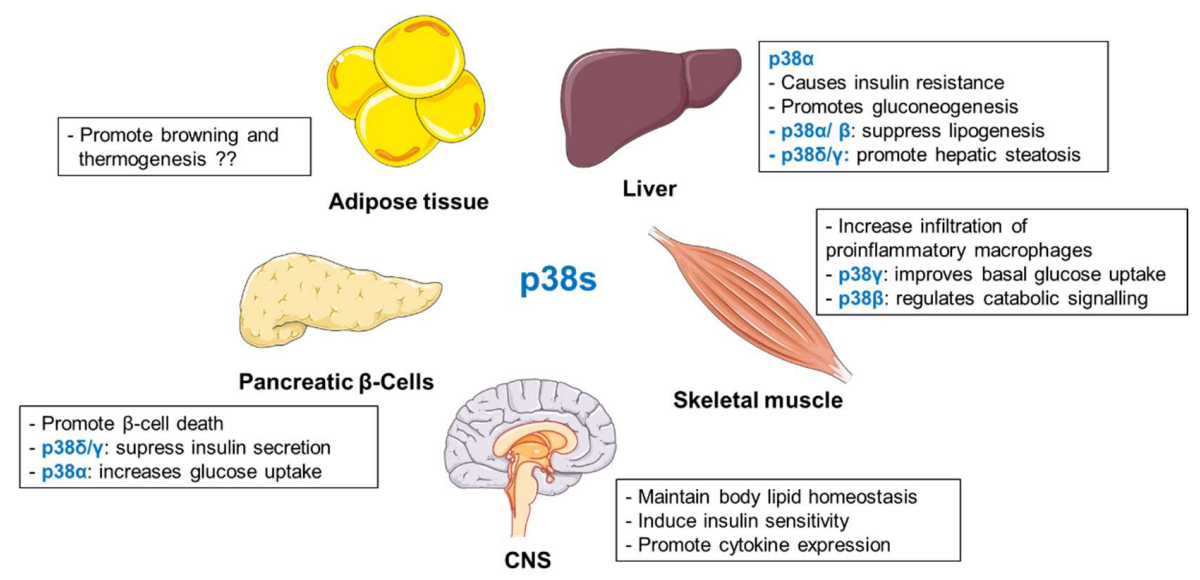

Figure 3. Organ-specific roles of p38 isoforms in regulation of metabolism.

Systemic knockout of ERK5 was shown to be embryonically lethal in mice because of defects in angiogenesis and vascular formation [215]. No obvious phenotype has been reported from hepatocyte-specific ERK5 knockout mice [216]. However, ERK5 deficiency in LepR-expressing neurons resulted in an obesity phenotype with enhanced WAT mass due to increased adipocyte size, but only in female mice fed a normal chow diet [217]. Moreover, impaired glucose homeostasis along with decreased physical activity, energy intake, and energy expenditure was observed in these animals. Although it has been reported that the deletion of ERK5 in adipose tissues using Adiponectin-Cre increased adiposity due to increased food intake, dysregulated secretion of adipokines, leptin resistance, and impaired glucose handling were also found in these mice [218]. In parallel, ERK5 was found to protect against pancreatic $\beta$-cell apoptosis and hyperglycaemia in mice by interrupting the ER stress-mediated apoptotic pathway [219]. Suppression of ERK5 activity in pregnant mice significantly decreased $\beta$-cell proliferation without affecting $\beta$-cell apoptosis, resulting in increased random blood glucose levels and impaired glucose response in mice [220]. ERK5 seemed to activate cyclin D1 to promote gestational $\beta$-cell proliferation.

\section{Summary}

More efforts are needed to elucidate the specific roles of ERK5 in regulation of metabolism. However, activation of ERK5 in multiple tissues seems to protect against development of obesity and diabetes (Figure 4).
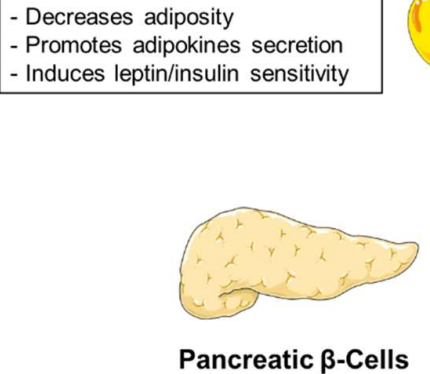

Pancreatic $\beta$-Cells

Promotes $\beta$-cell proliferation

Protects against $\beta$-cell apoptosis

Protects against hyperglycaemia

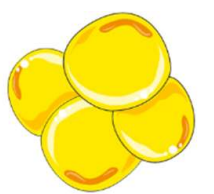

Adipose tissue

\section{ERK5}

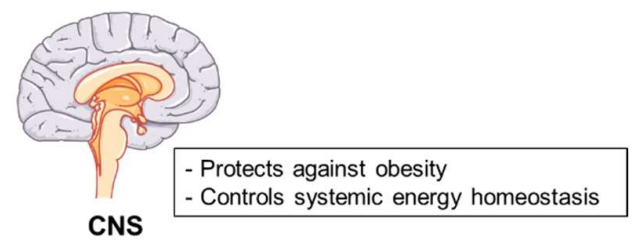

Figure 4. The impact of ERK5 on various tissues and organs. 


\section{The Atypical MAPKs}

Atypical MAP kinases include ERK3/ERK4, NLK, and ERK7. Much less is known about their regulation, substrate specificity, and physiological functions. Atypical MAPKs are not organized into classical three-tiered kinase cascades. In addition, the Thr-X-Tyr motif is absent in ERK3/4 and NLK, where a Gly or Glu residue replaces the Tyr. ERK7 contains the motif Thr-Glu-Tyr in its activation loop, but phosphorylation of these residues appears to be catalyzed by ERK7 itself, rather than by an upstream MAPKK (reviewed in [1,2]). While the conventional MAPKs signaling pathways that underlay metabolism have been well-studied, regulation of metabolism via atypical MAPKs signaling pathways is poorly understood.

Whereas the biological role of ERK4 is currently unknown, ERK3 has been shown to be involved in a number of biological functions, including cell proliferation, cell cycle progression, and cell differentiation [2]. ERK3 is a highly unstable protein that is constitutively degraded by the ubiquitin-proteasome pathway in proliferating cells [221]. In the cytoplasm, ERK3 is activated by the conventional PKC $\beta$ [222] and targets downstream activation of MAPK-activated protein kinase-5 (MK5) $[223,224]$. High throughput screen for kinases regulating lipolysis in adipocytes revealed ERK3 as a major factor promoting adipocyte function. Consistently, targeted deletion of ERK3 in mouse adipocytes inhibits lipolysis, but elevates energy dissipation, promoting lean phenotype and ameliorating diabetes [225]. Mechanistically, $\beta$-adrenergic stimulation stabilizes ERK3, leading to the formation of a complex with the cofactor MK5, and thereby driving lipolysis. ERK3/MK5 pathway promotes lipolysis by promoting the expression of a major lipase, adipose triglyceride lipase (ATGL), in a FOXO1-dependent manner [225]. On the other hand, depletion of ERK3 in adipocytes promotes UCP1 expression and energy dissipation by brown, as well as white, adipose tissue, thereby protecting against obesity and diabetes [225]. Pregnancy induces peripheral insulin resistance, which is normally compensated by increased $\beta$-cell proliferation, expansion of islet volume, and increased insulin synthesis and secretion. In fact, ERK3 is upregulated during pregnancy [226]. ERK3 expression is modulated by prolactin (PRL) in isolated rat pancreatic islets and seems to be involved in glucose-induced insulin release. This mechanism involves activation of the conventional protein kinase $C$ (PKC), leading to ERK3 serine phosphorylation and association with microtubule-associated protein 2 (MAP2) [226]. ERK3 seems also to play a key role in IL-8 production in a kinase-independent manner through its interaction with c-Jun. ERK3 controls the DNA-binding activity of the activating protein 1 (AP-1) transcription factor, which is critically required for the activation of several cytokines, including IL-8, by regulating c-Jun nuclear abundance [227]. These data indicate that ERK3 plays a central role in the regulation of adipocyte function. However, its function in other tissues needs to be explored.

NLK is part of the non-canonical Wnt signaling pathway that promotes osteogenesis and inhibits adipogenesis of mesenchymal stem cells [228-230]. In addition, NLK plays an important role in maintaining pre-adipocytes in an undifferentiated state by inhibiting adipogenic gene expression [231,232]. It has been reported that NLK-deficient mice exhibit increased adipocyte numbers in the bone marrow [233]. Moreover, the polymorphism of the NLK gene was significantly associated with human fat body mass [232], and with intramuscular fat content and FA composition traits in pigs [234].

Despite the lack of identified substrates, ERK7 and its human ortholog ERK8 play important biological functions, notably in the regulation of cell proliferation and in the response to estrogens and glucocorticoids [2]. In mammals, insulin-like signaling is mediated by insulin and insulin-like growth factors through their respective receptors. Drosophila possesses a single insulin-like receptor, which is activated by insulin-like peptides (dILPs), mainly expressed and secreted by a group of median neurosecretory cells, also known as insulin-producing cells (IPCs). Interestingly, ERK7 is essential to inhibit dILP secretion upon impaired ribosome biogenesis, and it acts epistatically to p53 [235]. Both p53 and ERK7 activities within the IPCs contribute to the regulation of dILP secretion in response to nutrient status. The p53- and ERK7-dependent ribosome surveillance pathway seems to serve as a local branch of the IPC-regulating nutrient-sensing network, parallel to the humoral signals derived from the fat body. 


\section{Summary}

The role of atypical MAPK in the regulation of metabolism is relatively poorly explored. However, ERK3 and NLK emerge as important regulators of adipocyte and pancreatic $\beta$-cell function (Figure 5). ERK3 promotes lipolysis in adipose tissue and suppresses energy dissipation in this organ [225]. ERK3 also promotes insulin secretion from the pancreatic $\beta$ cell [226]. NLK regulates adipose tissue homeostasis by suppressing adipogenesis [231,232].

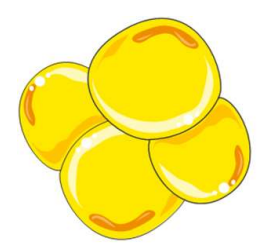

Adipose tissue

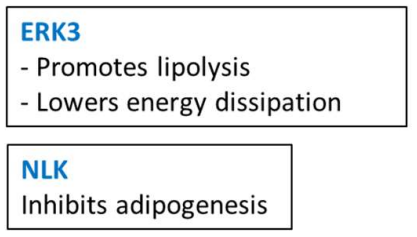

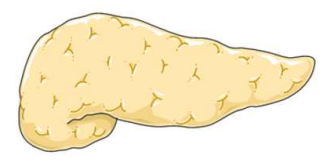

Pancreatic $\beta$-Cells

ERK3

- Promotes glucose-induced insulin release

- Induces cytokines production

Figure 5. The role of atypical MAPKs in regulation of metabolism.

\section{Conclusions, Future Perspective and Therapeutic Implications}

In summary, this review provides updated insights into the critical functions of MAPK-signaling pathways and their role in the development of metabolic diseases such as obesity and T2D. While initially research into MAPKs and metabolism has focused on the established ERK1/2, JNKs, and p38s MAPK families, it is now becoming apparent that ERK5, the most recently discovered MAPK, and atypical MAPKs, mainly ERK3, also play an important role in the regulation of metabolic homeostasis. Moreover, as described above, different studies suggest that the distinct isoforms of ERK1/2, JNKs, and p38s impact metabolism in diverse manners. However, further studies are needed to fully clarify the role of each of the members of the MAPK family in the development of metabolic disorders. Additionally, ERK3, ERK4, ERK5, ERK7/8, and NLK have not been thoroughly studied in vivo yet, and a limited number of substrates and functions have been annotated to these kinases. The use of genetically modified animals, especially conditionally deficient mouse models and molecular targeting strategies able to specifically inhibit particular MAPKs signaling pathways enabled to uncover the specific functions of the kinases from this family in organs implicated in regulating metabolic homeostasis (Table 2). However, further studies are needed to fully define the physiological roles of kinases from MAPK family in the regulation of metabolism and the development of metabolic diseases.

Importantly, understanding the regulation mechanisms of signal transduction by conventional MAPKs has provided useful information for the development of specific inhibitors, which eventually could be used in the clinical practice. In fact, drugs targeting MAPK pathways have already provided striking clinical responses, especially in inflammatory diseases and cancers [236,237]. Thus, targeting these kinases might also represent a promising avenue for the treatment of metabolic disorders such as obesity, diabetes, and atherosclerosis. Unfortunately, to date, conventional MAPKs are used mainly as markers for metabolic research trials (registered in clinicaltrial.gov: NCT02498119, NCT00330967, NCT03811717, NCT00524901, NCT01272674, NCT02498119, NCT00291902, NCT02367287, NCT02367287), and there is a very limited number of research trials targeting these kinases directly for treatment of obesity and diabetes. The dual $\alpha \beta$ subtype p38 inhibitor, losmapimod, modestly reduced vascular inflammation in stable atherosclerosis subjects, as measured by 18FDG-PET/CT [238]. Moreover, a significant reduction of inflammation in visceral fat and a persistent reduction in high sensitivity C-reactive peptide (hsCRP) were observed. 
However, BMS-582949, a novel highly selective p38 $\alpha$ inhibitor, does not lead to a significant reduction of either circulating inflammatory biomarkers or imaging measures of atherosclerotic inflammation [239]. These results indicate that inhibition of $p 38 \beta$ might be required in order to obtain the desired anti-inflammatory effects in atherosclerosis. Overall, currently available data suggest that inhibition of specific members of conventional and/or atypical MAPKs might be beneficial for the treatment of metabolic diseases. However, since MAPKs play a central role in normal biological functions, direct inhibition of these kinases may also have unexpected consequences. The development of highly selective inhibitors is therefore essential for the safe therapy of metabolic disorders.

Table 2. MAPKs and metabolic phenotype observed in genetic in vivo experiments. (-) indicates negatively regulated. $(+)$ indicates positively regulated. ?? indicates parameter was not investigated.

\begin{tabular}{|c|c|c|c|c|c|}
\hline & Liver & $\begin{array}{l}\text { Adipose } \\
\text { Tissue }\end{array}$ & $\begin{array}{c}\text { Pancreatic } \\
\beta \text {-Cells }\end{array}$ & Skeletal Muscle & CNS \\
\hline ERK1/2 & (-) insulin sensitivity & $\begin{array}{l}(-) \text { insulin sensitivity } \\
(+) \text { adiposity }\end{array}$ & $\begin{array}{l}+(+) \text { glucose-stimulated } \\
\text { insulin secretion } \\
(+) \beta \text {-cell survival }\end{array}$ & $? ?$ & $\begin{array}{c}(+) \text { energy expenditure } \\
(-) \text { adiposity } \\
(-) \text { food intake }\end{array}$ \\
\hline JNKs & contradictory results & $\begin{array}{c}(-) \text { hepatic insulin } \\
\text { sensitivity } \\
(+) \text { hepatic steatosis }\end{array}$ & $\beta$-cell dysfunction & $\begin{array}{l}\text { no effect on adiposity } \\
\text { contradictory } \\
\text { results on insulin } \\
\text { sensitivity }\end{array}$ & $\begin{array}{l}\text { (+) adiposity } \\
(-) \text { glucose tolerance } \\
(-) \text { insulin sensitivity } \\
(+) \text { hepatic steatosis }\end{array}$ \\
\hline p38s & $\begin{array}{c}\text { p38 } \alpha: \\
\text { (+) luconeogenesis } \\
\text { (+) fasting } \\
\text { hyperglycemia } \\
\text { p38 } \alpha / \beta \\
\text { (-) lipogenesis } \\
\text { p38 } \gamma / \text { p38 } \\
\text { (+) hepatic steatosis }\end{array}$ & $\begin{array}{l}\text { Contradictory } \\
\text { results }\end{array}$ & $\begin{array}{c}\text { p38s: } \\
\text { (-) insulin secretion } \\
\text { p38 } \alpha \text { : } \\
\text { (+) glucose uptake }\end{array}$ & $\begin{array}{c}\text { p38 } \gamma: \\
(+) \text { glucose uptake }\end{array}$ & ?? \\
\hline ERK5 & no obvious phenotype & $\begin{array}{l}\text { (-) adiposity } \\
(+) \text { leptin/insulin } \\
\text { sensitivity }\end{array}$ & (-) hyperglycaemia & $? ?$ & (-) adiposity \\
\hline ERK3 & $? ?$ & $\begin{array}{l}(-) \text { insulin sensitivity } \\
(+) \text { adiposity }\end{array}$ & $? ?$ & $? ?$ & $? ?$ \\
\hline
\end{tabular}

Author Contributions: T.K. and G.S. wrote the manuscript. All authors have read and agreed to the published version of the manuscript.

Funding: This study was funded by European Research Council (ERC) Starting Grant SicMetabol (no. 678119), EMBO Installation Grant from European Molecular Biology Organization (EMBO), and the Dioscuri Centre of Scientific Excellence. The program was initiated by the Max Planck Society (MPG), managed jointly with the National Science Centre and mutually funded by the Ministry of Science and Higher Education (MNiSW) and the German Federal Ministry of Education and Research (BMBF).

Acknowledgments: We thank Olga Sumara for critical reading of our manuscript. Authors would like to acknowledge Servier Medical Art by Servier (smart.servier.com) for sharing free images under a Creative Commons Attribution3.0 Unported License. Some elements from smart.servier.com were used for creating the figures.

Conflicts of Interest: The authors declare no conflict of interest.

\section{References}

1. Coulombe, P.; Meloche, S. Atypical mitogen-activated protein kinases: Structure, regulation and functions. Biochim. Biophys. Acta 2007, 1773, 1376-1387. [CrossRef] [PubMed]

2. Cargnello, M.; Roux, P.P. Activation and function of the MAPKs and their substrates, the MAPK-activated protein kinases. Microbiol. Mol. Biol. Rev. 2011, 75, 50-83. [CrossRef] [PubMed]

3. Kim, E.K.; Choi, E.J. Pathological roles of MAPK signaling pathways in human diseases. Biochim. Biophys. Acta 2010, 1802, 396-405. [CrossRef] [PubMed]

4. Gehart, H.; Kumpf, S.; Ittner, A.; Ricci, R. MAPK signaling in cellular metabolism: Stress or wellness? EMBO Rep. 2010, 11, 834-840. [CrossRef]

5. Pal, M.; Febbraio, M.A.; Lancaster, G.I. The roles of c-Jun NH2-terminal kinases (JNKs) in obesity and insulin resistance. J. Physiol. 2016, 594, 267-279. [CrossRef] 
6. Manieri, E.; Sabio, G. Stress kinases in the modulation of metabolism and energy balance. J. Mol. Endocrinol. 2015, 55, R11-R22. [CrossRef]

7. Boulton, T.G.; Yancopoulos, G.D.; Gregory, J.S.; Slaughter, C.; Moomaw, C.; Hsu, J.; Cobb, M.H. An insulin-stimulated protein kinase similar to yeast kinases involved in cell cycle control. Science 1990, 249, 64-67. [CrossRef]

8. Shaul, Y.D.; Seger, R. The MEK/ERK cascade: From signaling specificity to diverse functions. Biochim. Biophys. Acta 2007, 1773, 1213-1226. [CrossRef]

9. Carriere, A.; Ray, H.; Blenis, J.; Roux, P.P. The RSK factors of activating the Ras/MAPK signaling cascade. Front. Biosci. 2008, 13, 4258-4275. [CrossRef]

10. Reyskens, K.M.; Arthur, J.S. Emerging Roles of the Mitogen and Stress Activated Kinases MSK1 and MSK2. Front. Cell Dev. Biol 2016, 4, 56. [CrossRef]

11. Joshi, S.; Platanias, L.C. Mnk kinase pathway: Cellular functions and biological outcomes. World J. Biol. Chem. 2014, 5, 321-333. [CrossRef] [PubMed]

12. Babu, G.J.; Lalli, M.J.; Sussman, M.A.; Sadoshima, J.; Periasamy, M. Phosphorylation of elk-1 by MEK/ERK pathway is necessary for c-fos gene activation during cardiac myocyte hypertrophy. J. Mol. Cell Cardiol. 2000, 32, 1447-1457. [CrossRef] [PubMed]

13. Angel, P.; Karin, M. The role of Jun, Fos and the AP-1 complex in cell-proliferation and transformation. Biochim. Biophys. Acta 1991, 1072, 129-157. [CrossRef]

14. Whitmarsh, A.J. Regulation of gene transcription by mitogen-activated protein kinase signaling pathways. Biochim. Biophys. Acta 2007, 1773, 1285-1298. [CrossRef] [PubMed]

15. Viala, E.; Pouysségur, J. Regulation of tumor cell motility by ERK mitogen-activated protein kinases. Ann. N. Y. Acad. Sci. 2004, 1030, 208-218. [CrossRef]

16. Kalwat, M.A.; Thurmond, D.C. Signaling mechanisms of glucose-induced F-actin remodeling in pancreatic islet $\beta$ cells. Exp. Mol. Med. 2013, 45, e37. [CrossRef]

17. Smorodinsky-Atias, K.; Soudah, N.; Engelberg, D. Mutations That Confer Drug-Resistance, Oncogenicity and Intrinsic Activity on the ERK MAP Kinases-Current State of the Art. Cells 2020, 9. [CrossRef] [PubMed]

18. Roskoski, R. Targeting ERK1/2 protein-serine/threonine kinases in human cancers. Pharmacol. Res. 2019, 142, 151-168. [CrossRef]

19. Pagès, G.; Guérin, S.; Grall, D.; Bonino, F.; Smith, A.; Anjuere, F.; Auberger, P.; Pouysségur, J. Defective thymocyte maturation in p44 MAP kinase (Erk 1) knockout mice. Science 1999, 286, 1374-1377. [CrossRef]

20. Frémin, C.; Saba-El-Leil, M.K.; Lévesque, K.; Ang, S.L.; Meloche, S. Functional Redundancy of ERK1 and ERK2 MAP Kinases during Development. Cell Rep. 2015, 12, 913-921. [CrossRef]

21. Han, H.S.; Kang, G.; Kim, J.S.; Choi, B.H.; Koo, S.H. Regulation of glucose metabolism from a liver-centric perspective. Exp. Mol. Med. 2016, 48, e218. [CrossRef] [PubMed]

22. Jiao, P.; Feng, B.; Li, Y.; He, Q.; Xu, H. Hepatic ERK activity plays a role in energy metabolism. Mol. Cell Endocrinol. 2013, 375, 157-166. [CrossRef] [PubMed]

23. Zheng, Y.; Zhang, W.; Pendleton, E.; Leng, S.; Wu, J.; Chen, R.; Sun, X.J. Improved insulin sensitivity by calorie restriction is associated with reduction of ERK and p70S6K activities in the liver of obese Zucker rats. J. Endocrinol. 2009, 203, 337-347. [CrossRef]

24. Khan, A.S.; Subramaniam, S.; Dramane, G.; Khelifi, D.; Khan, N.A. ERK1 and ERK2 activation modulates diet-induced obesity in mice. Biochimie 2017, 137, 78-87. [CrossRef] [PubMed]

25. Feng, B.; Jiao, P.; Yang, Z.; Xu, H. MEK/ERK pathway mediates insulin-promoted degradation of MKP-3 protein in liver cells. Mol. Cell Endocrinol. 2012, 361, 116-123. [CrossRef] [PubMed]

26. Manowsky, J.; Camargo, R.G.; Kipp, A.P.; Henkel, J.; Püschel, G.P. Insulin-induced cytokine production in macrophages causes insulin resistance in hepatocytes. Am. J. Physiol. Endocrinol. Metab. 2016, 310, E938-E946. [CrossRef] [PubMed]

27. Fisher, F.M.; Estall, J.L.; Adams, A.C.; Antonellis, P.J.; Bina, H.A.; Flier, J.S.; Kharitonenkov, A.; Spiegelman, B.M.; Maratos-Flier, E. Integrated regulation of hepatic metabolism by fibroblast growth factor 21 (FGF21) in vivo. Endocrinology 2011, 152, 2996-3004. [CrossRef]

28. Wu, H.T.; Lu, F.H.; Ou, H.Y.; Su, Y.C.; Hung, H.C.; Wu, J.S.; Yang, Y.C.; Wu, C.L.; Chang, C.J. The role of hepassocin in the development of non-alcoholic fatty liver disease. J. Hepatol. 2013, 59, 1065-1072. [CrossRef] 
29. Wu, H.T.; Ou, H.Y.; Hung, H.C.; Su, Y.C.; Lu, F.H.; Wu, J.S.; Yang, Y.C.; Wu, C.L.; Chang, C.J. A novel hepatokine, HFREP1, plays a crucial role in the development of insulin resistance and type 2 diabetes. Diabetologia 2016, 59, 1732-1742. [CrossRef]

30. Studer, E.; Zhou, X.; Zhao, R.; Wang, Y.; Takabe, K.; Nagahashi, M.; Pandak, W.M.; Dent, P.; Spiegel, S.; Shi, R.; et al. Conjugated bile acids activate the sphingosine-1-phosphate receptor 2 in primary rodent hepatocytes. Hepatology 2012, 55, 267-276. [CrossRef]

31. Cao, R.; Cronk, Z.X.; Zha, W.; Sun, L.; Wang, X.; Fang, Y.; Studer, E.; Zhou, H.; Pandak, W.M.; Dent, P.; et al. Bile acids regulate hepatic gluconeogenic genes and farnesoid $X$ receptor via $G($ alpha)i-protein-coupled receptors and the AKT pathway. J. Lipid Res. 2010, 51, 2234-2244. [CrossRef] [PubMed]

32. Geng, S.; Zhu, W.; Wang, S.; Xie, C.; Li, X.; Wu, J.; Li, Y.; Chen, Y.; Wang, X.; Meng, Y.; et al. P53 modulates hepatic insulin sensitivity through NF-kB and p38/ERK MAPK pathways. Biochem. Biophys. Res. Commun. 2018, 495, 2139-2144. [CrossRef] [PubMed]

33. Liu, H.; Yu, J.; Xia, T.; Xiao, Y.; Zhang, Q.; Liu, B.; Guo, Y.; Deng, J.; Deng, Y.; Chen, S.; et al. Hepatic serum- and glucocorticoid-regulated protein kinase 1 (SGK1) regulates insulin sensitivity in mice via extracellular-signal-regulated kinase 1/2 (ERK1/2). Biochem. J. 2014, 464, 281-289. [CrossRef] [PubMed]

34. Cohen, P.; Spiegelman, B.M. Cell biology of fat storage. Mol. Biol Cell 2016, 27, 2523-2527. [CrossRef]

35. Hong, S.; Song, W.; Zushin, P.H.; Liu, B.; Jedrychowski, M.P.; Mina, A.I.; Deng, Z.; Cabarkapa, D.; Hall, J.A.; Palmer, C.J.; et al. Phosphorylation of Beta-3 adrenergic receptor at serine 247 by ERK MAP kinase drives lipolysis in obese adipocytes. Mol. Metab. 2018, 12, 25-38. [CrossRef]

36. Bost, F.; Aouadi, M.; Caron, L.; Even, P.; Belmonte, N.; Prot, M.; Dani, C.; Hofman, P.; Pagès, G.; Pouysségur, J.; et al. The extracellular signal-regulated kinase isoform ERK1 is specifically required for in vitro and in vivo adipogenesis. Diabetes 2005, 54, 402-411. [CrossRef]

37. Jager, J.; Corcelle, V.; Grémeaux, T.; Laurent, K.; Waget, A.; Pagès, G.; Binétruy, B.; Le Marchand-Brustel, Y.; Burcelin, R.; Bost, F.; et al. Deficiency in the extracellular signal-regulated kinase 1 (ERK1) protects leptin-deficient mice from insulin resistance without affecting obesity. Diabetologia 2011, 54, 180-189. [CrossRef]

38. Robidoux, J.; Kumar, N.; Daniel, K.W.; Moukdar, F.; Cyr, M.; Medvedev, A.V.; Collins, S. Maximal beta3-adrenergic regulation of lipolysis involves Src and epidermal growth factor receptor-dependent ERK1/2 activation. J. Biol. Chem. 2006, 281, 37794-37802. [CrossRef]

39. Rydén, M.; Arvidsson, E.; Blomqvist, L.; Perbeck, L.; Dicker, A.; Arner, P. Targets for TNF-alpha-induced lipolysis in human adipocytes. Biochem. Biophys. Res. Commun. 2004, 318, 168-175. [CrossRef]

40. Martin, S.; Parton, R.G. Lipid droplets: A unified view of a dynamic organelle. Nat. Rev. Mol. Cell Biol. 2006, 7, 373-378. [CrossRef]

41. Greenberg, A.S.; Shen, W.J.; Muliro, K.; Patel, S.; Souza, S.C.; Roth, R.A.; Kraemer, F.B. Stimulation of lipolysis and hormone-sensitive lipase via the extracellular signal-regulated kinase pathway. J. Biol. Chem. 2001, 276, 45456-45461. [CrossRef] [PubMed]

42. Rapold, R.A.; Wueest, S.; Knoepfel, A.; Schoenle, E.J.; Konrad, D. Fas activates lipolysis in a Ca2+-CaMKII-dependent manner in 3T3-L1 adipocytes. J. Lipid Res. 2013, 54, 63-70. [CrossRef] [PubMed]

43. Bost, F.; Caron, L.; Marchetti, I.; Dani, C.; Le Marchand-Brustel, Y.; Binétruy, B. Retinoic acid activation of the ERK pathway is required for embryonic stem cell commitment into the adipocyte lineage. Biochem. J. 2002, 361, 621-627. [CrossRef] [PubMed]

44. Kim, K.H.; Cho, Y.S.; Park, J.M.; Yoon, S.O.; Kim, K.W.; Chung, A.S. Pro-MMP-2 activation by the PPARgamma agonist, ciglitazone, induces cell invasion through the generation of ROS and the activation of ERK. FEBS Lett. 2007, 581, 3303-3310. [CrossRef] [PubMed]

45. Hu, E.; Kim, J.B.; Sarraf, P.; Spiegelman, B.M. Inhibition of adipogenesis through MAP kinase-mediated phosphorylation of PPARgamma. Science 1996, 274, 2100-2103. [CrossRef]

46. Wang, N.; Zhao, T.T.; Li, S.M.; Sun, X.; Li, Z.C.; Li, Y.H.; Li, D.S.; Wang, W.F. Fibroblast Growth Factor 21 Exerts its Anti-inflammatory Effects on Multiple Cell Types of Adipose Tissue in Obesity. Obesity (Silver Spring) 2019, 27, 399-408. [CrossRef]

47. Chang, C.C.; Chen, C.Y.; Wen, H.C.; Huang, C.Y.; Hung, M.S.; Lu, H.C.; Chen, W.L.; Chang, C.H. Caveolin-1 Secreted from Adipose Tissues and Adipocytes Functions as an Adipogenesis Enhancer. Obesity (Silver Spring) 2017, 25, 1932-1940. [CrossRef] 
48. Wu, H.T.; Chen, S.C.; Fan, K.C.; Kuo, C.H.; Lin, S.Y.; Wang, S.H.; Chang, C.J.; Li, H.Y. Targeting fibrinogen-like protein 1 is a novel therapeutic strategy to combat obesity. FASEB J. 2020, 34, 2958-2967. [CrossRef]

49. Lindquist, J.M.; Rehnmark, S. Ambient temperature regulation of apoptosis in brown adipose tissue. Erk1/2 promotes norepinephrine-dependent cell survival. J. Biol. Chem. 1998, 273, 30147-30156. [CrossRef]

50. Than, A.; Xu, S.; Li, R.; Leow, M.K.; Sun, L.; Chen, P. Erratum: Author Correction: Angiotensin type 2 receptor activation promotes browning of white adipose tissue and brown adipogenesis. Signal. Transduct Target Ther. 2018, 3, 1. [CrossRef]

51. Choe, S.S.; Huh, J.Y.; Hwang, I.J.; Kim, J.I.; Kim, J.B. Adipose Tissue Remodeling: Its Role in Energy Metabolism and Metabolic Disorders. Front. Endocrinol. 2016, 7, 30. [CrossRef] [PubMed]

52. McNelis, J.C.; Olefsky, J.M. Macrophages, immunity, and metabolic disease. Immunity 2014, 41, 36-48. [CrossRef] [PubMed]

53. Guilherme, A.; Virbasius, J.V.; Puri, V.; Czech, M.P. Adipocyte dysfunctions linking obesity to insulin resistance and type 2 diabetes. Nat. Rev. Mol. Cell Biol. 2008, 9, 367-377. [CrossRef] [PubMed]

54. Fujishiro, M.; Gotoh, Y.; Katagiri, H.; Sakoda, H.; Ogihara, T.; Anai, M.; Onishi, Y.; Ono, H.; Abe, M.; Shojima, N.; et al. Three mitogen-activated protein kinases inhibit insulin signaling by different mechanisms in 3T3-L1 adipocytes. Mol. Endocrinol. 2003, 17, 487-497. [CrossRef]

55. Fischer, A.M.; Katayama, C.D.; Pagès, G.; Pouysségur, J.; Hedrick, S.M. The role of erk1 and erk2 in multiple stages of $\mathrm{T}$ cell development. Immunity 2005, 23, 431-443. [CrossRef]

56. Richardson, E.T.; Shukla, S.; Nagy, N.; Boom, W.H.; Beck, R.C.; Zhou, L.; Landreth, G.E.; Harding, C.V. ERK Signaling Is Essential for Macrophage Development. PLoS ONE 2015, 10, e0140064. [CrossRef]

57. Molgat, A.S.; Gagnon, A.; Sorisky, A. Preadipocyte apoptosis is prevented by macrophage-conditioned medium in a PDGF-dependent manner. Am. J. Physiol. Cell Physiol. 2009, 296, C757-C765. [CrossRef]

58. Molgat, A.S.; Gagnon, A.; Sorisky, A. Macrophage-induced preadipocyte survival depends on signaling through Akt, ERK1/2, and reactive oxygen species. Exp. Cell Res. 2011, 317, 521-530. [CrossRef]

59. Constant, V.A.; Gagnon, A.; Yarmo, M.; Sorisky, A. The antiadipogenic effect of macrophage-conditioned medium depends on ERK1/2 activation. Metabolism 2008, 57, 465-472. [CrossRef]

60. Huang, Z.; Zhong, L.; Lee, J.T.H.; Zhang, J.; Wu, D.; Geng, L.; Wang, Y.; Wong, C.M.; Xu, A. The FGF21-CCL11 Axis Mediates Beiging of White Adipose Tissues by Coupling Sympathetic Nervous System to Type 2 Immunity. Cell Metab. 2017, 26, 493-508.e494. [CrossRef]

61. Habibian, J.S.; Jefic, M.; Bagchi, R.A.; Lane, R.H.; McKnight, R.A.; McKinsey, T.A.; Morrison, R.F.; Ferguson, B.S. DUSP5 functions as a feedback regulator of TNF $\alpha$-induced ERK1/2 dephosphorylation and inflammatory gene expression in adipocytes. Sci. Rep. 2017, 7, 1-11. [CrossRef] [PubMed]

62. Sakamoto, T.; Takahashi, N.; Sawaragi, Y.; Naknukool, S.; Yu, R.; Goto, T.; Kawada, T. Inflammation induced by RAW macrophages suppresses UCP1 mRNA induction via ERK activation in 10T1/2 adipocytes. Am. J. Physiol. Cell Physiol. 2013, 304, C729-C738. [CrossRef] [PubMed]

63. Goto, T.; Naknukool, S.; Yoshitake, R.; Hanafusa, Y.; Tokiwa, S.; Li, Y.; Sakamoto, T.; Nitta, T.; Kim, M.; Takahashi, N.; et al. Proinflammatory cytokine interleukin-1 $\beta$ suppresses cold-induced thermogenesis in adipocytes. Cytokine 2016, 77, 107-114. [CrossRef] [PubMed]

64. Czech, M.P. Insulin action and resistance in obesity and type 2 diabetes. Nat. Med. 2017, $23,804-814$. [CrossRef]

65. Šrámek, J.; Němcová-Fürstová, V.; Kovář, J. Kinase Signaling in Apoptosis Induced by Saturated Fatty Acids in Pancreatic $\beta$-Cells. Int. J. Mol. Sci. 2016, 17. [CrossRef]

66. Sidarala, V.; Kowluru, A. The Regulatory Roles of Mitogen-Activated Protein Kinase (MAPK) Pathways in Health and Diabetes: Lessons Learned from the Pancreatic $\beta$-Cell. Recent Pat. Endocr. Metab. Immune Drug Discov. 2017, 10, 76-84. [CrossRef]

67. Benes, C.; Roisin, M.P.; Van Tan, H.; Creuzet, C.; Miyazaki, J.; Fagard, R. Rapid activation and nuclear translocation of mitogen-activated protein kinases in response to physiological concentration of glucose in the MIN6 pancreatic beta cell line. J. Biol. Chem. 1998, 273, 15507-15513. [CrossRef]

68. Benes, C.; Poitout, V.; Marie, J.C.; Martin-Perez, J.; Roisin, M.P.; Fagard, R. Mode of regulation of the extracellular signal-regulated kinases in the pancreatic beta-cell line MIN6 and their implication in the regulation of insulin gene transcription. Biochem. J. 1999, 340, 219-225. [CrossRef] 
69. Longuet, C.; Broca, C.; Costes, S.; Hani, E.H.; Bataille, D.; Dalle, S. Extracellularly regulated kinases 1/2 (p44/42 mitogen-activated protein kinases) phosphorylate synapsin I and regulate insulin secretion in the MIN6 beta-cell line and islets of Langerhans. Endocrinology 2005, 146, 643-654. [CrossRef]

70. Leduc, M.; Richard, J.; Costes, S.; Muller, D.; Varrault, A.; Compan, V.; Mathieu, J.; Tanti, J.F.; Pagès, G.; Pouyssegur, J.; et al. ERK1 is dispensable for mouse pancreatic beta cell function but is necessary for glucose-induced full activation of MSK1 and CREB. Diabetologia 2017, 60, 1999-2010. [CrossRef]

71. Arnette, D.; Gibson, T.B.; Lawrence, M.C.; January, B.; Khoo, S.; McGlynn, K.; Vanderbilt, C.A.; Cobb, M.H. Regulation of ERK1 and ERK2 by glucose and peptide hormones in pancreatic beta cells. J. Biol. Chem. 2003, 278, 32517-32525. [CrossRef] [PubMed]

72. Trümper, J.; Ross, D.; Jahr, H.; Brendel, M.D.; Göke, R.; Hörsch, D. The Rap-B-Raf signaling pathway is activated by glucose and glucagon-like peptide-1 in human islet cells. Diabetologia 2005, 48, 1534-1540. [CrossRef] [PubMed]

73. Wijesekara, N.; Krishnamurthy, M.; Bhattacharjee, A.; Suhail, A.; Sweeney, G.; Wheeler, M.B. Adiponectin-induced ERK and Akt phosphorylation protects against pancreatic beta cell apoptosis and increases insulin gene expression and secretion. J. Biol. Chem. 2010, 285, 33623-33631. [CrossRef] [PubMed]

74. Egan, B.; Zierath, J.R. Exercise metabolism and the molecular regulation of skeletal muscle adaptation. Cell Metab. 2013, 17, 162-184. [CrossRef]

75. Goodyear, L.J.; Chang, P.Y.; Sherwood, D.J.; Dufresne, S.D.; Moller, D.E. Effects of exercise and insulin on mitogen-activated protein kinase signaling pathways in rat skeletal muscle. Am. J. Physiol. 1996, 271, E403-E408. [CrossRef] [PubMed]

76. Leng, Y.; Steiler, T.L.; Zierath, J.R. Effects of insulin, contraction, and phorbol esters on mitogen-activated protein kinase signaling in skeletal muscle from lean and ob/ob mice. Diabetes 2004, 53, 1436-1444. [CrossRef]

77. Seaberg, B.; Henslee, G.; Wang, S.; Paez-Colasante, X.; Landreth, G.E.; Rimer, M. Muscle-derived extracellular signal-regulated kinases 1 and 2 are required for the maintenance of adult myofibers and their neuromuscular junctions. Mol. Cell Biol. 2015, 35, 1238-1253. [CrossRef]

78. Barreto, R.; Waning, D.L.; Gao, H.; Liu, Y.; Zimmers, T.A.; Bonetto, A. Chemotherapy-related cachexia is associated with mitochondrial depletion and the activation of ERK1/2 and p38 MAPKs. Oncotarget 2016, 7, 43442-43460. [CrossRef]

79. Pu, J.; Peng, G.; Li, L.; Na, H.; Liu, Y.; Liu, P. Palmitic acid acutely stimulates glucose uptake via activation of Akt and ERK1/2 in skeletal muscle cells. J. Lipid Res. 2011, 52, 1319-1327. [CrossRef]

80. Wu, W.; Sun, Y.; Zhao, C.; Chen, X.; Wang, G.; Pang, W.; Yang, G. Lipogenesis in myoblasts and its regulation of CTRP6 by AdipoR1/Erk/PPAR $\gamma$ signaling pathway. Acta Biochim. Biophys. Sin. (Shanghai) 2016, 48, 509-519. [CrossRef]

81. Montori-Grau, M.; Tarrats, N.; Osorio-Conles, O.; Orozco, A.; Serrano-Marco, L.; Vázquez-Carrera, M.; Gómez-Foix, A.M. Glucose dependence of glycogen synthase activity regulation by GSK3 and MEK/ERK inhibitors and angiotensin-(1-7) action on these pathways in cultured human myotubes. Cell Signal. 2013, 25, 1318-1327. [CrossRef] [PubMed]

82. Behera, S.; Kapadia, B.; Kain, V.; Alamuru-Yellapragada, N.P.; Murunikkara, V.; Kumar, S.T.; Babu, P.P.; Seshadri, S.; Shivarudraiah, P.; Hiriyan, J.; et al. ERK1/2 activated PHLPP1 induces skeletal muscle ER stress through the inhibition of a novel substrate AMPK. Biochim Biophys Acta Mol. Basis Dis. 2018, 1864, 1702-1716. [CrossRef] [PubMed]

83. Belgardt, B.F.; Brüning, J.C. CNS leptin and insulin action in the control of energy homeostasis. Ann. N. Y. Acad. Sci. 2010, 1212, 97-113. [CrossRef] [PubMed]

84. Waterson, M.J.; Horvath, T.L. Neuronal Regulation of Energy Homeostasis: Beyond the Hypothalamus and Feeding. Cell Metab. 2015, 22, 962-970. [CrossRef]

85. Zhang, J.; Zhou, Y.; Chen, C.; Yu, F.; Wang, Y.; Gu, J.; Ma, L.; Ho, G. ERK1/2 mediates glucose-regulated POMC gene expression in hypothalamic neurons. J. Mol. Endocrinol. 2015, 54, 125-135. [CrossRef]

86. Morikawa, Y.; Ueyama, E.; Senba, E. Fasting-induced activation of mitogen-activated protein kinases (ERK/p38) in the mouse hypothalamus. J. Neuroendocrinol. 2004, 16, 105-112. [CrossRef]

87. Ueyama, E.; Morikawa, Y.; Yasuda, T.; Senba, E. Attenuation of fasting-induced phosphorylation of mitogen-activated protein kinases $(E R K / p 38)$ in the mouse hypothalamus in response to refeeding. Neurosci Lett. 2004, 371, 40-44. [CrossRef] 
88. Rodrigues, B.A.; Muñoz, V.R.; Kuga, G.K.; Gaspar, R.C.; Nakandakari, S.C.B.R.; Crisol, B.M.; Botezelli, J.D.; Pauli, L.S.S.; da Silva, A.S.R.; de Moura, L.P.; et al. Obesity Increases Mitogen-Activated Protein Kinase Phosphatase-3 Levels in the Hypothalamus of Mice. Front. Cell Neurosci. 2017, 11, 313. [CrossRef]

89. Rahmouni, K.; Sigmund, C.D.; Haynes, W.G.; Mark, A.L. Hypothalamic ERK mediates the anorectic and thermogenic sympathetic effects of leptin. Diabetes 2009, 58, 536-542. [CrossRef]

90. Myers, M.G. Leptin receptor signaling and the regulation of mammalian physiology. Recent Prog. Horm. Res. 2004, 59, 287-304. [CrossRef]

91. Gaspar, R.C.; Muñoz, V.R.; Kuga, G.K.; Nakandakari, S.C.B.R.; Minuzzi, L.G.; Botezelli, J.D.; da Silva, A.S.R.; Cintra, D.E.; de Moura, L.P.; Ropelle, E.R.; et al. Acute physical exercise increases leptin-induced hypothalamic extracellular signal-regulated kinase1/2 phosphorylation and thermogenesis of obese mice. J. Cell Biochem. 2019, 120, 697-704. [CrossRef] [PubMed]

92. Liang, Q.; Zhong, L.; Zhang, J.; Wang, Y.; Bornstein, S.R.; Triggle, C.R.; Ding, H.; Lam, K.S.; Xu, A. FGF21 maintains glucose homeostasis by mediating the cross talk between liver and brain during prolonged fasting. Diabetes 2014, 63, 4064-4075. [CrossRef] [PubMed]

93. Filippi, B.M.; Yang, C.S.; Tang, C.; Lam, T.K. Insulin activates Erk1/2 signaling in the dorsal vagal complex to inhibit glucose production. Cell Metab. 2012, 16, 500-510. [CrossRef] [PubMed]

94. Filippi, B.M.; Bassiri, A.; Abraham, M.A.; Duca, F.A.; Yue, J.T.; Lam, T.K. Insulin signals through the dorsal vagal complex to regulate energy balance. Diabetes 2014, 63, 892-899. [CrossRef]

95. Subramaniam, S.; Ozdener, M.H.; Abdoul-Azize, S.; Saito, K.; Malik, B.; Maquart, G.; Hashimoto, T.; Marambaud, P.; Aribi, M.; Tordoff, M.G.; et al. ERK1/2 activation in human taste bud cells regulates fatty acid signaling and gustatory perception of fat in mice and humans. FASEB J. 2016, 30, 3489-3500. [CrossRef]

96. Davis, R.J. Signal transduction by the JNK group of MAP kinases. Cell 2000, 103, 239-252. [CrossRef]

97. Weston, C.R.; Davis, R.J. The JNK signal transduction pathway. Curr. Opin. Genet. Dev. 2002, 12, 14-21. [CrossRef]

98. Li, L.; Feng, Z.; Porter, A.G. JNK-dependent phosphorylation of c-Jun on serine 63 mediates nitric oxide-induced apoptosis of neuroblastoma cells. J. Biol. Chem. 2004, 279, 4058-4065. [CrossRef]

99. Aoki, H.; Kang, P.M.; Hampe, J.; Yoshimura, K.; Noma, T.; Matsuzaki, M.; Izumo, S. Direct activation of mitochondrial apoptosis machinery by c-Jun N-terminal kinase in adult cardiac myocytes. J. Biol. Chem. 2002, 277, 10244-10250. [CrossRef]

100. Dhanasekaran, D.N.; Reddy, E.P. JNK signaling in apoptosis. Oncogene 2008, 27, 6245-6251. [CrossRef]

101. Ricci, R.; Sumara, G.; Sumara, I.; Rozenberg, I.; Kurrer, M.; Akhmedov, A.; Hersberger, M.; Eriksson, U.; Eberli, F.R.; Becher, B.; et al. Requirement of JNK2 for scavenger receptor A-mediated foam cell formation in atherogenesis. Science 2004, 306, 1558-1561. [CrossRef] [PubMed]

102. Sumara, G.; Belwal, M.; Ricci, R. “Jnking” atherosclerosis. Cell Mol. Life Sci. 2005, 62, 2487-2494. [CrossRef] [PubMed]

103. Hirosumi, J.; Tuncman, G.; Chang, L.; Görgün, C.Z.; Uysal, K.T.; Maeda, K.; Karin, M.; Hotamisligil, G.S. A central role for JNK in obesity and insulin resistance. Nature 2002, 420, 333-336. [CrossRef] [PubMed]

104. Chung, J.; Nguyen, A.K.; Henstridge, D.C.; Holmes, A.G.; Chan, M.H.; Mesa, J.L.; Lancaster, G.I.; Southgate, R.J.; Bruce, C.R.; Duffy, S.J.; et al. HSP72 protects against obesity-induced insulin resistance. Proc. Natl. Acad. Sci. USA 2008, 105, 1739-1744. [CrossRef] [PubMed]

105. Boden, G.; Duan, X.; Homko, C.; Molina, E.J.; Song, W.; Perez, O.; Cheung, P.; Merali, S. Increase in endoplasmic reticulum stress-related proteins and genes in adipose tissue of obese, insulin-resistant individuals. Diabetes 2008, 57, 2438-2444. [CrossRef] [PubMed]

106. Carvalho, B.M.; Oliveira, A.G.; Ueno, M.; Araújo, T.G.; Guadagnini, D.; Carvalho-Filho, M.A.; Geloneze, B.; Lima, M.M.; Pareja, J.C.; Carvalheira, J.B.; et al. Modulation of double-stranded RNA-activated protein kinase in insulin sensitive tissues of obese humans. Obesity (Silver Spring) 2013, 21, 2452-2457. [CrossRef]

107. Tuncman, G.; Hirosumi, J.; Solinas, G.; Chang, L.; Karin, M.; Hotamisligil, G.S. Functional in vivo interactions between JNK1 and JNK2 isoforms in obesity and insulin resistance. Proc. Natl. Acad. Sci. USA 2006, 103, 10741-10746. [CrossRef]

108. Yang, R.; Wilcox, D.M.; Haasch, D.L.; Jung, P.M.; Nguyen, P.T.; Voorbach, M.J.; Doktor, S.; Brodjian, S.; Bush, E.N.; Lin, E.; et al. Liver-specific knockdown of JNK1 up-regulates proliferator-activated receptor gamma coactivator 1 beta and increases plasma triglyceride despite reduced glucose and insulin levels in diet-induced obese mice. J. Biol. Chem. 2007, 282, 22765-22774. [CrossRef] 
109. Nakatani, Y.; Kaneto, H.; Kawamori, D.; Hatazaki, M.; Miyatsuka, T.; Matsuoka, T.A.; Kajimoto, Y.; Matsuhisa, M.; Yamasaki, Y.; Hori, M. Modulation of the JNK pathway in liver affects insulin resistance status. J. Biol. Chem. 2004, 279, 45803-45809. [CrossRef]

110. Vernia, S.; Cavanagh-Kyros, J.; Garcia-Haro, L.; Sabio, G.; Barrett, T.; Jung, D.Y.; Kim, J.K.; Xu, J.; Shulha, H.P.; Garber, M.; et al. The PPAR $\alpha$-FGF21 hormone axis contributes to metabolic regulation by the hepatic JNK signaling pathway. Cell Metab. 2014, 20, 512-525. [CrossRef]

111. Aguirre, V.; Uchida, T.; Yenush, L.; Davis, R.; White, M.F. The c-Jun NH(2)-terminal kinase promotes insulin resistance during association with insulin receptor substrate-1 and phosphorylation of Ser(307). J. Biol. Chem. 2000, 275, 9047-9054. [CrossRef] [PubMed]

112. Copps, K.D.; Hancer, N.J.; Opare-Ado, L.; Qiu, W.; Walsh, C.; White, M.F. Irs1 serine 307 promotes insulin sensitivity in mice. Cell Metab. 2010, 11, 84-92. [CrossRef] [PubMed]

113. Sabio, G.; Cavanagh-Kyros, J.; Ko, H.J.; Jung, D.Y.; Gray, S.; Jun, J.Y.; Barrett, T.; Mora, A.; Kim, J.K.; Davis, R.J. Prevention of steatosis by hepatic JNK1. Cell Metab. 2009, 10, 491-498. [CrossRef] [PubMed]

114. Sabio, G.; Das, M.; Mora, A.; Zhang, Z.; Jun, J.Y.; Ko, H.J.; Barrett, T.; Kim, J.K.; Davis, R.J. A stress signaling pathway in adipose tissue regulates hepatic insulin resistance. Science 2008, 322, 1539-1543. [CrossRef] [PubMed]

115. Han, M.S.; Jung, D.Y.; Morel, C.; Lakhani, S.A.; Kim, J.K.; Flavell, R.A.; Davis, R.J. JNK expression by macrophages promotes obesity-induced insulin resistance and inflammation. Science 2013, 339, $218-222$. [CrossRef]

116. Galic, S.; Sachithanandan, N.; Kay, T.W.; Steinberg, G.R. Suppressor of cytokine signaling (SOCS) proteins as guardians of inflammatory responses critical for regulating insulin sensitivity. Biochem. J. 2014, 461, 177-188. [CrossRef] [PubMed]

117. Shimizu, T.; Yamakuchi, M.; Biswas, K.K.; Aryal, B.; Yamada, S.; Hashiguchi, T.; Maruyama, I. HMGB1 is secreted by 3T3-L1 adipocytes through JNK signaling and the secretion is partially inhibited by adiponectin. Obesity (Silver Spring) 2016, 24, 1913-1921. [CrossRef]

118. Jaeschke, A.; Czech, M.P.; Davis, R.J. An essential role of the JIP1 scaffold protein for JNK activation in adipose tissue. Genes Dev. 2004, 18, 1976-1980. [CrossRef]

119. Kou, Y.; Liu, Q.; Liu, W.; Sun, H.; Liang, M.; Kong, F.; Zhang, B.; Wei, Y.; Liu, Z.; Wang, Y. LIGHT/TNFSF14 signaling attenuates beige fat biogenesis. FASEB J. 2019, 33, 1595-1604. [CrossRef]

120. Yuliana, A.; Daijo, A.; Jheng, H.F.; Kwon, J.; Nomura, W.; Takahashi, H.; Ara, T.; Kawada, T.; Goto, T. Endoplasmic Reticulum Stress Impaired Uncoupling Protein 1 Expression via the Suppression of Peroxisome Proliferator-Activated Receptor $\gamma$ Binding Activity in Mice Beige Adipocytes. Int. J. Mol. Sci. 2019, 20. [CrossRef]

121. Solinas, G.; Vilcu, C.; Neels, J.G.; Bandyopadhyay, G.K.; Luo, J.L.; Naugler, W.; Grivennikov, S.; Wynshaw-Boris, A.; Scadeng, M.; Olefsky, J.M.; et al. JNK1 in hematopoietically derived cells contributes to diet-induced inflammation and insulin resistance without affecting obesity. Cell Metab. 2007, 6, 386-397. [CrossRef] [PubMed]

122. Vallerie, S.N.; Furuhashi, M.; Fucho, R.; Hotamisligil, G.S. A predominant role for parenchymal c-Jun amino terminal kinase (JNK) in the regulation of systemic insulin sensitivity. PLoS ONE 2008, 3, e3151. [CrossRef] [PubMed]

123. Zhang, X.; Xu, A.; Chung, S.K.; Cresser, J.H.; Sweeney, G.; Wong, R.L.; Lin, A.; Lam, K.S. Selective inactivation of c-Jun NH2-terminal kinase in adipose tissue protects against diet-induced obesity and improves insulin sensitivity in both liver and skeletal muscle in mice. Diabetes 2011, 60, 486-495. [CrossRef] [PubMed]

124. Perry, R.J.; Camporez, J.G.; Kursawe, R.; Titchenell, P.M.; Zhang, D.; Perry, C.J.; Jurczak, M.J.; Abudukadier, A.; Han, M.S.; Zhang, X.M.; et al. Hepatic acetyl CoA links adipose tissue inflammation to hepatic insulin resistance and type 2 diabetes. Cell 2015, 160, 745-758. [CrossRef] [PubMed]

125. Jaeschke, A.; Rincón, M.; Doran, B.; Reilly, J.; Neuberg, D.; Greiner, D.L.; Shultz, L.D.; Rossini, A.A.; Flavell, R.A.; Davis, R.J. Disruption of the Jnk2 (Mapk9) gene reduces destructive insulitis and diabetes in a mouse model of type I diabetes. Proc. Natl. Acad. Sci. USA 2005, 102, 6931-6935. [CrossRef]

126. Ammendrup, A.; Maillard, A.; Nielsen, K.; Aabenhus Andersen, N.; Serup, P.; Dragsbaek Madsen, O.; Mandrup-Poulsen, T.; Bonny, C. The c-Jun amino-terminal kinase pathway is preferentially activated by interleukin-1 and controls apoptosis in differentiating pancreatic beta-cells. Diabetes 2000, 49, 1468-1476. [CrossRef] 
127. Major, C.D.; Wolf, B.A. Interleukin-1beta stimulation of c-Jun NH(2)-terminal kinase activity in insulin-secreting cells: Evidence for cytoplasmic restriction. Diabetes 2001, 50, 2721-2728. [CrossRef]

128. Maedler, K.; Schulthess, F.T.; Bielman, C.; Berney, T.; Bonny, C.; Prentki, M.; Donath, M.Y.; Roduit, R. Glucose and leptin induce apoptosis in human beta-cells and impair glucose-stimulated insulin secretion through activation of c-Jun N-terminal kinases. FASEB J. 2008, 22, 1905-1913. [CrossRef]

129. Subramanian, S.L.; Hull, R.L.; Zraika, S.; Aston-Mourney, K.; Udayasankar, J.; Kahn, S.E. cJUN N-terminal kinase (JNK) activation mediates islet amyloid-induced beta cell apoptosis in cultured human islet amyloid polypeptide transgenic mouse islets. Diabetologia 2012, 55, 166-174. [CrossRef]

130. Tang, C.; Yeung, L.S.N.; Koulajian, K.; Zhang, L.; Tai, K.; Volchuk, A.; Giacca, A. Glucose-Induced $\beta$-Cell Dysfunction In Vivo: Evidence for a Causal Role of C-jun N-terminal Kinase Pathway. Endocrinology 2018, 159, 3643-3654. [CrossRef]

131. Verma, G.; Bhatia, H.; Datta, M. JNK1/2 regulates ER-mitochondrial Ca2+ cross-talk during IL-1 $\beta$-mediated cell death in RINm5F and human primary $\beta$-cells. Mol. Biol. Cell 2013, 24, 2058-2071. [CrossRef] [PubMed]

132. Kawamori, D.; Kaneto, H.; Nakatani, Y.; Matsuoka, T.A.; Matsuhisa, M.; Hori, M.; Yamasaki, Y. The forkhead transcription factor Foxo1 bridges the JNK pathway and the transcription factor PDX-1 through its intracellular translocation. J. Biol. Chem. 2006, 281, 1091-1098. [CrossRef]

133. Haefliger, J.A.; Tawadros, T.; Meylan, L.; Gurun, S.L.; Roehrich, M.E.; Martin, D.; Thorens, B.; Waeber, G. The scaffold protein IB1/JIP-1 is a critical mediator of cytokine-induced apoptosis in pancreatic beta cells. J. Cell Sci. 2003, 116, 1463-1469. [CrossRef] [PubMed]

134. Standen, C.L.; Kennedy, N.J.; Flavell, R.A.; Davis, R.J. Signal transduction cross talk mediated by Jun $\mathrm{N}$-terminal kinase-interacting protein and insulin receptor substrate scaffold protein complexes. Mol. Cell Biol. 2009, 29, 4831-4840. [CrossRef] [PubMed]

135. Abdelli, S.; Bonny, C. JNK3 maintains expression of the insulin receptor substrate 2 (IRS2) in insulin-secreting cells: Functional consequences for insulin signaling. PLoS ONE 2012, 7, e35997. [CrossRef] [PubMed]

136. Prause, M.; Christensen, D.P.; Billestrup, N.; Mandrup-Poulsen, T. JNK1 protects against glucolipotoxicity-mediated beta-cell apoptosis. PLoS ONE 2014, 9, e87067. [CrossRef]

137. Henstridge, D.C.; Bruce, C.R.; Pang, C.P.; Lancaster, G.I.; Allen, T.L.; Estevez, E.; Gardner, T.; Weir, J.M.; Meikle, P.J.; Lam, K.S.L.; et al. Skeletal muscle-specific overproduction of constitutively activated c-Jun $\mathrm{N}$-terminal kinase (JNK) induces insulin resistance in mice. Diabetologia 2012, 55, 2769-2778. [CrossRef]

138. Pal, M.; Wunderlich, C.M.; Spohn, G.; Brönneke, H.S.; Schmidt-Supprian, M.; Wunderlich, F.T. Alteration of JNK-1 signaling in skeletal muscle fails to affect glucose homeostasis and obesity-associated insulin resistance in mice. PLoS ONE 2013, 8, e54247. [CrossRef]

139. Sabio, G.; Kennedy, N.J.; Cavanagh-Kyros, J.; Jung, D.Y.; Ko, H.J.; Ong, H.; Barrett, T.; Kim, J.K.; Davis, R.J. Role of muscle c-Jun NH2-terminal kinase 1 in obesity-induced insulin resistance. Mol. Cell Biol. 2010, 30, 106-115. [CrossRef]

140. Jung, T.W.; Chung, Y.H.; Kim, H.C.; Abd El-Aty, A.M.; Jeong, J.H. Hyperlipidemia-induced hepassocin in the liver contributes to insulin resistance in skeletal muscle. Mol. Cell Endocrinol. 2018, 470, 26-33. [CrossRef]

141. Tsaousidou, E.; Paeger, L.; Belgardt, B.F.; Pal, M.; Wunderlich, C.M.; Brönneke, H.; Collienne, U.; Hampel, B.; Wunderlich, F.T.; Schmidt-Supprian, M.; et al. Distinct Roles for JNK and IKK Activation in Agouti-Related Peptide Neurons in the Development of Obesity and Insulin Resistance. Cell Rep. 2014, 9, 1495-1506. [CrossRef] [PubMed]

142. Sabio, G.; Cavanagh-Kyros, J.; Barrett, T.; Jung, D.Y.; Ko, H.J.; Ong, H.; Morel, C.; Mora, A.; Reilly, J.; Kim, J.K.; et al. Role of the hypothalamic-pituitary-thyroid axis in metabolic regulation by JNK1. Genes Dev. 2010, 24, 256-264. [CrossRef] [PubMed]

143. Vernia, S.; Cavanagh-Kyros, J.; Barrett, T.; Jung, D.Y.; Kim, J.K.; Davis, R.J. Diet-induced obesity mediated by the JNK/DIO2 signal transduction pathway. Genes Dev. 2013, 27, 2345-2355. [CrossRef] [PubMed]

144. Quiñones, M.; Al-Massadi, O.; Folgueira, C.; Bremser, S.; Gallego, R.; Torres-Leal, L.; Haddad-Tóvolli, R.; García-Caceres, C.; Hernandez-Bautista, R.; Lam, B.Y.H.; et al. p53 in AgRP neurons is required for protection against diet-induced obesity via JNK1. Nat. Commun. 2018, 9, 1-16. [CrossRef] [PubMed]

145. Martínez-Sánchez, N.; Seoane-Collazo, P.; Contreras, C.; Varela, L.; Villarroya, J.; Rial-Pensado, E.; Buqué, X.; Aurrekoetxea, I.; Delgado, T.C.; Vázquez-Martínez, R.; et al. Hypothalamic AMPK-ER Stress-JNK1 Axis Mediates the Central Actions of Thyroid Hormones on Energy Balance. Cell Metab. 2017, 26, $212-229$. [CrossRef] 
146. Cuadrado, A.; Nebreda, A.R. Mechanisms and functions of p38 MAPK signaling. Biochem. J. 2010, 429, 403-417. [CrossRef]

147. Lambert, P.F.; Kashanchi, F.; Radonovich, M.F.; Shiekhattar, R.; Brady, J.N. Phosphorylation of p53 serine 15 increases interaction with CBP. J. Biol. Chem. 1998, 273, 33048-33053. [CrossRef]

148. Loughery, J.; Cox, M.; Smith, L.M.; Meek, D.W. Critical role for p53-serine 15 phosphorylation in stimulating transactivation at p53-responsive promoters. Nucleic Acids Res. 2014, 42, 7666-7680. [CrossRef]

149. Teodoro, T.; Odisho, T.; Sidorova, E.; Volchuk, A. Pancreatic $\beta$-cells depend on basal expression of active ATF6 $\alpha$-p50 for cell survival even under nonstress conditions. Am. J. Physiol. Cell Physiol. 2012, 302, C992-C1003. [CrossRef]

150. Luo, S.; Lee, A.S. Requirement of the p38 mitogen-activated protein kinase signaling pathway for the induction of the $78 \mathrm{kDa}$ glucose-regulated protein/immunoglobulin heavy-chain binding protein by azetidine stress: Activating transcription factor 6 as a target for stress-induced phosphorylation. Biochem. J. 2002, 366, 787-795. [CrossRef]

151. Schieven, G.L. The biology of p38 kinase: A central role in inflammation. Curr. Top. Med. Chem. 2005, 5, 921-928. [CrossRef] [PubMed]

152. Cuenda, A.; Rousseau, S. p38 MAP-kinases pathway regulation, function and role in human diseases. Biochim. Biophys. Acta Mol. Cell Res. 2007, 1773, 1358-1375. [CrossRef] [PubMed]

153. Hemi, R.; Yochananov, Y.; Barhod, E.; Kasher-Meron, M.; Karasik, A.; Tirosh, A.; Kanety, H. p38 mitogen-activated protein kinase-dependent transactivation of ErbB receptor family: A novel common mechanism for stress-induced IRS-1 serine phosphorylation and insulin resistance. Diabetes 2011, 60, 1134-1145. [CrossRef] [PubMed]

154. Jing, Y.; Liu, W.; Cao, H.; Zhang, D.; Yao, X.; Zhang, S.; Xia, H.; Li, D.; Wang, Y.C.; Yan, J.; et al. Hepatic p38 $\alpha$ regulates gluconeogenesis by suppressing AMPK. J. Hepatol. 2015, 62, 1319-1327. [CrossRef] [PubMed]

155. González-Terán, B.; Matesanz, N.; Nikolic, I.; Verdugo, M.A.; Sreeramkumar, V.; Hernández-Cosido, L.; Mora, A.; Crainiciuc, G.; Sáiz, M.L.; Bernardo, E.; et al. p38 $\gamma$ and p38 reprogram liver metabolism by modulating neutrophil infiltration. EMBO J. 2016, 35, 536-552. [CrossRef] [PubMed]

156. Cao, W.; Collins, Q.F.; Becker, T.C.; Robidoux, J.; Lupo, E.G.; Xiong, Y.; Daniel, K.W.; Floering, L.; Collins, S. p38 Mitogen-activated protein kinase plays a stimulatory role in hepatic gluconeogenesis. J. Biol. Chem. 2005, 280, 42731-42737. [CrossRef] [PubMed]

157. Puigserver, P.; Rhee, J.; Lin, J.; Wu, Z.; Yoon, J.C.; Zhang, C.Y.; Krauss, S.; Mootha, V.K.; Lowell, B.B.; Spiegelman, B.M. Cytokine stimulation of energy expenditure through p38 MAP kinase activation of PPARgamma coactivator-1. Mol. Cell 2001, 8, 971-982. [CrossRef]

158. Miller, A.L.; Webb, M.S.; Copik, A.J.; Wang, Y.; Johnson, B.H.; Kumar, R.; Thompson, E.B. p38 Mitogen-activated protein kinase (MAPK) is a key mediator in glucocorticoid-induced apoptosis of lymphoid cells: Correlation between 38 MAPK activation and site-specific phosphorylation of the human glucocorticoid receptor at serine 211. Mol. Endocrinol. 2005, 19, 1569-1583. [CrossRef]

159. Itoh, M.; Adachi, M.; Yasui, H.; Takekawa, M.; Tanaka, H.; Imai, K. Nuclear export of glucocorticoid receptor is enhanced by c-Jun N-terminal kinase-mediated phosphorylation. Mol. Endocrinol. 2002, 16, 2382-2392. [CrossRef]

160. Krstic, M.D.; Rogatsky, I.; Yamamoto, K.R.; Garabedian, M.J. Mitogen-activated and cyclin-dependent protein kinases selectively and differentially modulate transcriptional enhancement by the glucocorticoid receptor. Mol. Cell Biol. 1997, 17, 3947-3954. [CrossRef]

161. Juge-Aubry, C.E.; Hammar, E.; Siegrist-Kaiser, C.; Pernin, A.; Takeshita, A.; Chin, W.W.; Burger, A.G.; Meier, C.A. Regulation of the transcriptional activity of the peroxisome proliferator-activated receptor alpha by phosphorylation of a ligand-independent trans-activating domain. J. Biol. Chem. 1999, 274, 10505-10510. [CrossRef] [PubMed]

162. Deak, M.; Clifton, A.D.; Lucocq, L.M.; Alessi, D.R. Mitogen- and stress-activated protein kinase-1 (MSK1) is directly activated by MAPK and SAPK2/p38, and may mediate activation of CREB. EMBO J. 1998, 17, 4426-4441. [CrossRef] [PubMed]

163. Qiao, L.; MacDougald, O.A.; Shao, J. CCAAT/enhancer-binding protein alpha mediates induction of hepatic phosphoenolpyruvate carboxykinase by p38 mitogen-activated protein kinase. J. Biol. Chem. 2006, 281, 24390-24397. [CrossRef] [PubMed] 
164. Yang, J.; Croniger, C.M.; Lekstrom-Himes, J.; Zhang, P.; Fenyus, M.; Tenen, D.G.; Darlington, G.J.; Hanson, R.W. Metabolic response of mice to a postnatal ablation of CCAAT/enhancer-binding protein alpha. J. Biol. Chem. 2005, 280, 38689-38699. [CrossRef] [PubMed]

165. Lee, J.; Sun, C.; Zhou, Y.; Gokalp, D.; Herrema, H.; Park, S.W.; Davis, R.J.; Ozcan, U. p38 MAPK-mediated regulation of Xbp1s is crucial for glucose homeostasis. Nat. Med. 2011, 17, 1251-1260. [CrossRef]

166. Xiong, Y.; Collins, Q.F.; An, J.; Lupo, E.; Liu, H.Y.; Liu, D.; Robidoux, J.; Liu, Z.; Cao, W. p38 mitogen-activated protein kinase plays an inhibitory role in hepatic lipogenesis. J. Biol. Chem. 2007, 282, 4975-4982. [CrossRef]

167. Huang, Z.; Wu, L.M.; Zhang, J.L.; Sabri, A.; Wang, S.J.; Qin, G.J.; Guo, C.Q.; Wen, H.T.; Du, B.B.; Zhang, D.H.; et al. Dual Specificity Phosphatase 12 Regulates Hepatic Lipid Metabolism Through Inhibition of the Lipogenesis and Apoptosis Signal-Regulating Kinase 1 Pathways. Hepatology 2019, 70, 1099-1118. [CrossRef]

168. Wang, S.; Yan, Z.Z.; Yang, X.; An, S.; Zhang, K.; Qi, Y.; Zheng, J.; Ji, Y.X.; Wang, P.X.; Fang, C.; et al. Hepatocyte DUSP14 maintains metabolic homeostasis and suppresses inflammation in the liver. Hepatology 2018, 67, 1320-1338. [CrossRef]

169. Ye, P.; Liu, J.; Xu, W.; Liu, D.; Ding, X.; Le, S.; Zhang, H.; Chen, S.; Chen, M.; Xia, J. Dual-Specificity Phosphatase 26 Protects Against Nonalcoholic Fatty Liver Disease in Mice Through Transforming Growth Factor Beta-Activated Kinase 1 Suppression. Hepatology 2019, 69, 1946-1964. [CrossRef]

170. Tang, P.; Low, H.B.; Png, C.W.; Torta, F.; Kumar, J.K.; Lim, H.Y.; Zhou, Y.; Yang, H.; Angeli, V.; Shabbir, A.; et al. Protective Function of Mitogen-Activated Protein Kinase Phosphatase 5 in Aging- and Diet-Induced Hepatic Steatosis and Steatohepatitis. Hepatol. Commun. 2019, 3, 748-762. [CrossRef]

171. Wang, Y.; Yan, S.; Xiao, B.; Zuo, S.; Zhang, Q.; Chen, G.; Yu, Y.; Chen, D.; Liu, Q.; Liu, Y.; et al. Prostaglandin F. Diabetes 2018, 67, 1748-1760. [CrossRef] [PubMed]

172. Cao, W.; Daniel, K.W.; Robidoux, J.; Puigserver, P.; Medvedev, A.V.; Bai, X.; Floering, L.M.; Spiegelman, B.M.; Collins, S. p38 mitogen-activated protein kinase is the central regulator of cyclic AMP-dependent transcription of the brown fat uncoupling protein 1 gene. Mol. Cell Biol. 2004, 24, 3057-3067. [CrossRef] [PubMed]

173. Matesanz, N.; Bernardo, E.; Acín-Pérez, R.; Manieri, E.; Pérez-Sieira, S.; Hernández-Cosido, L.; Montalvo-Romeral, V.; Mora, A.; Rodríguez, E.; Leiva-Vega, L.; et al. MKK6 controls T3-mediated browning of white adipose tissue. Nat. Commun. 2017, 8, 1-4. [CrossRef] [PubMed]

174. Tseng, Y.H.; Kokkotou, E.; Schulz, T.J.; Huang, T.L.; Winnay, J.N.; Taniguchi, C.M.; Tran, T.T.; Suzuki, R.; Espinoza, D.O.; Yamamoto, Y.; et al. New role of bone morphogenetic protein 7 in brown adipogenesis and energy expenditure. Nature 2008, 454, 1000-1004. [CrossRef] [PubMed]

175. Zhang, Y.; Li, R.; Meng, Y.; Li, S.; Donelan, W.; Zhao, Y.; Qi, L.; Zhang, M.; Wang, X.; Cui, T.; et al. Irisin stimulates browning of white adipocytes through mitogen-activated protein kinase p38 MAP kinase and ERK MAP kinase signaling. Diabetes 2014, 63, 514-525. [CrossRef] [PubMed]

176. Zhang, S.; Cao, H.; Li, Y.; Jing, Y.; Liu, S.; Ye, C.; Wang, H.; Yu, S.; Peng, C.; Hui, L.; et al. Metabolic benefits of inhibition of p38 $\alpha$ in white adipose tissue in obesity. PLoS Biol. 2018, 16, e2004225. [CrossRef] [PubMed]

177. Matesanz, N.; Nikolic, I.; Leiva, M.; Pulgarín-Alfaro, M.; Santamans, A.M.; Bernardo, E.; Mora, A.; Herrera-Melle, L.; Rodríguez, E.; Beiroa, D.; et al. p38 $\alpha$ blocks brown adipose tissue thermogenesis through p38 inhibition. PLoS Biol. 2018, 16, e2004455. [CrossRef]

178. Mottillo, E.P.; Shen, X.J.; Granneman, J.G. beta3-adrenergic receptor induction of adipocyte inflammation requires lipolytic activation of stress kinases p38 and JNK. Biochim. Biophys. Acta 2010, 1801, 1048-1055. [CrossRef]

179. Engelman, J.A.; Lisanti, M.P.; Scherer, P.E. Specific inhibitors of p38 mitogen-activated protein kinase block 3T3-L1 adipogenesis. J. Biol. Chem. 1998, 273, 32111-32120. [CrossRef]

180. Tanaka, T.; Yoshida, N.; Kishimoto, T.; Akira, S. Defective adipocyte differentiation in mice lacking the C/EBPbeta and/or C/EBPdelta gene. EMBO J. 1997, 16, 7432-7443. [CrossRef] 
181. Aouadi, M.; Laurent, K.; Prot, M.; Le Marchand-Brustel, Y.; Binétruy, B.; Bost, F. Inhibition of p38MAPK increases adipogenesis from embryonic to adult stages. Diabetes 2006, 55, 281-289. [CrossRef] [PubMed]

182. Yamaguchi, K.; Takeda, K.; Kadowaki, H.; Ueda, I.; Namba, Y.; Ouchi, Y.; Nishitoh, H.; Ichijo, H. Involvement of ASK1-p38 pathway in the pathogenesis of diabetes triggered by pancreatic $B$ cell exhaustion. Biochim. Biophys. Acta 2013, 1830, 3656-3663. [CrossRef]

183. Wei, X.; Gu, N.; Feng, N.; Guo, X.; Ma, X. Inhibition of p38 mitogen-activated protein kinase exerts a hypoglycemic effect by improving $\beta$ cell function via inhibition of $\beta$ cell apoptosis in $\mathrm{db} / \mathrm{db}$ mice. J. Enzyme Inhib. Med. Chem. 2018, 33, 1494-1500. [CrossRef]

184. Balakrishnan, S.; Sadasivam, M.; Kannan, A.; Panneerselvam, A.; Prahalathan, C. Glucose modulates Pax6 expression through the JNK/p38 MAP kinase pathway in pancreatic beta-cells. Life Sci. 2014, 109, 1-7. [CrossRef] [PubMed]

185. Song, H.; Wohltmann, M.; Tan, M.; Bao, S.; Ladenson, J.H.; Turk, J. Group VIA PLA2 (iPLA2 $\beta$ ) is activated upstream of p38 mitogen-activated protein kinase (MAPK) in pancreatic islet $\beta$-cell signaling. J. Biol. Chem. 2012, 287, 5528-5541. [CrossRef]

186. Sumara, G.; Formentini, I.; Collins, S.; Sumara, I.; Windak, R.; Bodenmiller, B.; Ramracheya, R.; Caille, D.; Jiang, H.; Platt, K.A.; et al. Regulation of PKD by the MAPK p38delta in insulin secretion and glucose homeostasis. Cell 2009, 136, 235-248. [CrossRef] [PubMed]

187. Goginashvili, A.; Zhang, Z.; Erbs, E.; Spiegelhalter, C.; Kessler, P.; Mihlan, M.; Pasquier, A.; Krupina, K.; Schieber, N.; Cinque, L.; et al. Insulin granules. Insulin secretory granules control autophagy in pancreatic $\beta$ cells. Science 2015, 347, 878-882. [CrossRef]

188. Lyu, J.; Imachi, H.; Yoshimoto, T.; Fukunaga, K.; Sato, S.; Ibata, T.; Kobayashi, T.; Dong, T.; Yonezaki, K.; Yamaji, N.; et al. Thyroid stimulating hormone stimulates the expression of glucose transporter 2 via its receptor in pancreatic $\beta$ cell line, INS-1 cells. Sci. Rep. 2018, 8, 1-10. [CrossRef]

189. Sato, S.; Imachi, H.; Lyu, J.; Miyai, Y.; Fukunaga, K.; Dong, T.; Ibata, T.; Kobayashi, T.; Yoshimoto, T.; Kikuchi, F.; et al. Effect of TNF- $\alpha$ on the expression of ABCA1 in pancreatic $\beta$-cells. J. Mol. Endocrinol. 2018, 61, 185-193. [CrossRef]

190. Zhang, S.; Kaplan, M.H. The p38 mitogen-activated protein kinase is required for IL-12-induced IFN-gamma expression. J. Immunol. 2000, 165, 1374-1380. [CrossRef]

191. Rincón, M.; Enslen, H.; Raingeaud, J.; Recht, M.; Zapton, T.; Su, M.S.; Penix, L.A.; Davis, R.J.; Flavell, R.A. Interferon-gamma expression by Th1 effector T cells mediated by the p38 MAP kinase signaling pathway. EMBO J. 1998, 17, 2817-2829. [CrossRef] [PubMed]

192. Yang, W.S.; Park, Y.C.; Kim, J.H.; Kim, H.R.; Yu, T.; Byeon, S.E.; Unsworth, L.D.; Lee, J.; Cho, J.Y. Nanostructured, self-assembling peptide K5 blocks TNF- $\alpha$ and $\mathrm{PGE}_{2}$ production by suppression of the AP-1/p38 pathway. Mediators Inflamm. 2012, 2012. [CrossRef]

193. Kang, Y.J.; Chen, J.; Otsuka, M.; Mols, J.; Ren, S.; Wang, Y.; Han, J. Macrophage deletion of p38alpha partially impairs lipopolysaccharide-induced cellular activation. J. Immunol. 2008, 180, 5075-5082. [CrossRef] [PubMed]

194. Risco, A.; del Fresno, C.; Mambol, A.; Alsina-Beauchamp, D.; MacKenzie, K.F.; Yang, H.T.; Barber, D.F.; Morcelle, C.; Arthur, J.S.; Ley, S.C.; et al. p38 $\gamma$ and p38 8 kinases regulate the Toll-like receptor 4 (TLR4)-induced cytokine production by controlling ERK1/2 protein kinase pathway activation. Proc. Natl. Acad. Sci. USA 2012, 109, 11200-11205. [CrossRef]

195. González-Terán, B.; Cortés, J.R.; Manieri, E.; Matesanz, N.; Verdugo, Á.; Rodríguez, M.E.; González-Rodríguez, Á.; Valverde, Á.; Valverde, Á.; Martín, P.; et al. Eukaryotic elongation factor 2 controls TNF- $\alpha$ translation in LPS-induced hepatitis. J. Clin. Investig. 2013, 123, 164-178. [CrossRef] [PubMed]

196. Ittner, A.; Block, H.; Reichel, C.A.; Varjosalo, M.; Gehart, H.; Sumara, G.; Gstaiger, M.; Krombach, F.; Zarbock, A.; Ricci, R. Regulation of PTEN activity by p38 -PKD1 signaling in neutrophils confers inflammatory responses in the lung. J. Exp. Med. 2012, 209, 2229-2246. [CrossRef]

197. Bertola, A.; Park, O.; Gao, B. Chronic plus binge ethanol feeding synergistically induces neutrophil infiltration and liver injury in mice: A critical role for E-selectin. Hepatology 2013, 58, 1814-1823. [CrossRef] 
198. Koistinen, H.A.; Chibalin, A.V.; Zierath, J.R. Aberrant p38 mitogen-activated protein kinase signaling in skeletal muscle from Type 2 diabetic patients. Diabetologia 2003, 46, 1324-1328. [CrossRef]

199. Brown, A.E.; Palsgaard, J.; Borup, R.; Avery, P.; Gunn, D.A.; De Meyts, P.; Yeaman, S.J.; Walker, M. p38 MAPK activation upregulates proinflammatory pathways in skeletal muscle cells from insulin-resistant type 2 diabetic patients. Am. J. Physiol. Endocrinol. Metab. 2015, 308, E63-E70. [CrossRef]

200. Wang, X.; Zhao, D.; Cui, Y.; Lu, S.; Gao, D.; Liu, J. Proinflammatory macrophages impair skeletal muscle differentiation in obesity through secretion of tumor necrosis factor- $\alpha$ via sustained activation of p38 mitogen-activated protein kinase. J. Cell Physiol. 2019, 234, 2566-2580. [CrossRef]

201. Fukawa, T.; Yan-Jiang, B.C.; Min-Wen, J.C.; Jun-Hao, E.T.; Huang, D.; Qian, C.N.; Ong, P.; Li, Z.; Chen, S.; Mak, S.Y.; et al. Excessive fatty acid oxidation induces muscle atrophy in cancer cachexia. Nat. Med. 2016, 22, 666-671. [CrossRef] [PubMed]

202. Bosquet, A.; Girona, J.; Guaita-Esteruelas, S.; Heras, M.; Saavedra-García, P.; Martínez-Micaelo, N.; Masana, L.; Rodríguez-Calvo, R. FABP4 inhibitor BMS309403 decreases saturated-fatty-acid-induced endoplasmic reticulum stress-associated inflammation in skeletal muscle by reducing p38 MAPK activation. Biochim. Biophys. Acta, Mol. Cell Biol. Lipids 2018, 1863, 604-613. [CrossRef] [PubMed]

203. Ohki, K.; Wakui, H.; Kishio, N.; Azushima, K.; Uneda, K.; Haku, S.; Kobayashi, R.; Haruhara, K.; Kinguchi, S.; Yamaji, T.; et al. Angiotensin II Type 1 Receptor-associated Protein Inhibits Angiotensin II-induced Insulin Resistance with Suppression of Oxidative Stress in Skeletal Muscle Tissue. Sci. Rep. 2018, 8, 1-2. [CrossRef] [PubMed]

204. Lawan, A.; Min, K.; Zhang, L.; Canfran-Duque, A.; Jurczak, M.J.; Camporez, J.P.G.; Nie, Y.; Gavin, T.P.; Shulman, G.I.; Fernandez-Hernando, C.; et al. Skeletal Muscle-Specific Deletion of MKP-1 Reveals a p38 MAPK/JNK/Akt Signaling Node That Regulates Obesity-Induced Insulin Resistance. Diabetes 2018, 67, 624-635. [CrossRef]

205. Yuasa, K.; Okubo, K.; Yoda, M.; Otsu, K.; Ishii, Y.; Nakamura, M.; Itoh, Y.; Horiuchi, K. Targeted ablation of p38 $\alpha$ MAPK suppresses denervation-induced muscle atrophy. Sci. Rep. 2018, 8, 1-9. [CrossRef]

206. Pogozelski, A.R.; Geng, T.; Li, P.; Yin, X.; Lira, V.A.; Zhang, M.; Chi, J.T.; Yan, Z. p38gamma mitogen-activated protein kinase is a key regulator in skeletal muscle metabolic adaptation in mice. PLoS ONE 2009, 4, e7934. [CrossRef]

207. Ho, R.C.; Alcazar, O.; Fujii, N.; Hirshman, M.F.; Goodyear, L.J. p38gamma MAPK regulation of glucose transporter expression and glucose uptake in L6 myotubes and mouse skeletal muscle. Am. J. Physiol. Regul. Integr. Comp. Physiol. 2004, 286, R342-R349. [CrossRef]

208. Zhang, G.; Li, Y.P. p38 $\beta$ MAPK upregulates atrogin1/MAFbx by specific phosphorylation of C/EBP $\beta$. Skelet Muscle 2012, 2, 1-9. [CrossRef]

209. Ding, H.; Zhang, G.; Sin, K.W.; Liu, Z.; Lin, R.K.; Li, M.; Li, Y.P. Activin A induces skeletal muscle catabolism via p38 $\beta$ mitogen-activated protein kinase. J. Cachexia. Sarcopenia. 2017, 8, 202-212. [CrossRef]

210. Geller, S.; Arribat, Y.; Netzahualcoyotzi, C.; Lagarrigue, S.; Carneiro, L.; Zhang, L.; Amati, F.; Lopez-Mejia, I.C.; Pellerin, L. Tanycytes Regulate Lipid Homeostasis by Sensing Free Fatty Acids and Signaling to Key Hypothalamic Neuronal Populations via FGF21 Secretion. Cell Metab. 2019, 30, 833-844. [CrossRef]

211. Ramakrishnan, R.; Kempuraj, D.; Prabhakaran, K.; Jayakumar, A.R.; Devi, R.S.; Suthanthirarajan, N.; Namasivayam, A. A short-term diabetes induced changes of catecholamines and p38-MAPK in discrete areas of rat brain. Life Sci. 2005, 77, 1825-1835. [CrossRef]

212. Liao, M.J.; Lin, H.; He, Y.W.; Zou, C. NFATc3 deficiency protects against high fat diet (HFD)-induced hypothalamus inflammation and apoptosis via p38 and JNK suppression. Biochem. Biophys. Res. Commun. 2018, 499, 743-750. [CrossRef] [PubMed]

213. Benomar, Y.; Gertler, A.; De Lacy, P.; Crépin, D.; Ould Hamouda, H.; Riffault, L.; Taouis, M. Central resistin overexposure induces insulin resistance through Toll-like receptor 4. Diabetes 2013, 62, 102-114. [CrossRef] [PubMed]

214. Nithianandarajah-Jones, G.N.; Wilm, B.; Goldring, C.E.; Müller, J.; Cross, M.J. ERK5: Structure, regulation and function. Cell Signal. 2012, 24, 2187-2196. [CrossRef] [PubMed]

215. Regan, C.P.; Li, W.; Boucher, D.M.; Spatz, S.; Su, M.S.; Kuida, K. Erk5 null mice display multiple extraembryonic vascular and embryonic cardiovascular defects. Proc. Natl. Acad. Sci. USA 2002, 99, 9248-9253. [CrossRef] [PubMed] 
216. Hayashi, M.; Lee, J.D. Role of the BMK1/ERK5 signaling pathway: Lessons from knockout mice. J. Mol. Med. (Berl) 2004, 82, 800-808. [CrossRef]

217. Horie, T.; Park, G.; Inaba, Y.; Hashiuchi, E.; Iezaki, T.; Tokumura, K.; Fukasawa, K.; Yamada, T.; Hiraiwa, M.; Kitaguchi, Y.; et al. MAPK Erk5 in Leptin Receptor-Expressing Neurons Controls Body Weight and Systemic Energy Homeostasis in Female Mice. Endocrinology 2019, 160, 2837-2848. [CrossRef]

218. Zhu, H.; Guariglia, S.; Li, W.; Brancho, D.; Wang, Z.V.; Scherer, P.E.; Chow, C.W. Role of extracellular signal-regulated kinase 5 in adipocyte signaling. J. Biol. Chem. 2014, 289, 6311-6322. [CrossRef]

219. Nam, D.H.; Han, J.H.; Lim, J.H.; Park, K.M.; Woo, C.H. CHOP Deficiency Ameliorates ERK5 Inhibition-Mediated Exacerbation of Streptozotocin-Induced Hyperglycemia and Pancreatic $\beta$-Cell Apoptosis. Mol. Cells 2017, 40,457-465. [CrossRef]

220. Chen, C.; Wu, S.; Lin, X.; Wu, D.; Fischbach, S.; Xiao, X. ERK5 plays an essential role in gestational beta-cell proliferation. Cell Prolif. 2018, 51, e12410. [CrossRef]

221. Coulombe, P.; Rodier, G.; Pelletier, S.; Pellerin, J.; Meloche, S. Rapid turnover of extracellular signal-regulated kinase 3 by the ubiquitin-proteasome pathway defines a novel paradigm of mitogen-activated protein kinase regulation during cellular differentiation. Mol. Cell Biol. 2003, 23, 4542-4558. [CrossRef] [PubMed]

222. Sauma, S.; Friedman, E. Increased expression of protein kinase $C$ beta activates ERK3. J. Biol. Chem. 1996, 271, 11422-11426. [CrossRef] [PubMed]

223. Seternes, O.M.; Mikalsen, T.; Johansen, B.; Michaelsen, E.; Armstrong, C.G.; Morrice, N.A.; Turgeon, B.; Meloche, S.; Moens, U.; Keyse, S.M. Activation of MK5/PRAK by the atypical MAP kinase ERK3 defines a novel signal transduction pathway. EMBO J. 2004, 23, 4780-4791. [CrossRef] [PubMed]

224. Schumacher, S.; Laass, K.; Kant, S.; Shi, Y.; Visel, A.; Gruber, A.D.; Kotlyarov, A.; Gaestel, M. Scaffolding by ERK3 regulates MK5 in development. EMBO J. 2004, 23, 4770-4779. [CrossRef] [PubMed]

225. El-Merahbi, R.; Viera, J.T.; Valdes, A.L.; Kolczynska, K.; Reuter, S.; Löffler, M.C.; Erk, M.; Ade, C.P.; Karwen, T.; Mayer, A.E.; et al. The adrenergic-induced ERK3 pathway drives lipolysis and suppresses energy dissipation. Genes Dev. 2020. [CrossRef] [PubMed]

226. Anhê, G.F.; Torrão, A.S.; Nogueira, T.C.; Caperuto, L.C.; Amaral, M.E.; Medina, M.C.; Azevedo-Martins, A.K.; Carpinelli, A.R.; Carvalho, C.R.; Curi, R.; et al. ERK3 associates with MAP2 and is involved in glucose-induced insulin secretion. Mol. Cell Endocrinol. 2006, 251, 33-41. [CrossRef] [PubMed]

227. Bogucka, K.; Pompaiah, M.; Marini, F.; Binder, H.; Harms, G.; Kaulich, M.; Klein, M.; Michel, C.; Radsak, M.P.; Rosigkeit, S. ERK3/MAPK6 controls IL-8 production and chemotaxis. Elife 2020, 9, e52511. [CrossRef]

228. Okamura, M.; Inagaki, T.; Tanaka, T.; Sakai, J. Role of histone methylation and demethylation in adipogenesis and obesity. Organogenesis 2010, 6, 24-32. [CrossRef]

229. Takada, I.; Kouzmenko, A.P.; Kato, S. PPAR-gamma Signaling Crosstalk in Mesenchymal Stem Cells. PPAR Res. 2010, 2010. [CrossRef]

230. Cristancho, A.G.; Lazar, M.A. Forming functional fat: A growing understanding of adipocyte differentiation. Nat. Rev. Mol. Cell Biol. 2011, 12, 722-734. [CrossRef]

231. Ross, S.E.; Hemati, N.; Longo, K.A.; Bennett, C.N.; Lucas, P.C.; Erickson, R.L.; MacDougald, O.A. Inhibition of adipogenesis by Wnt signaling. Science 2000, 289, 950-953. [CrossRef] [PubMed]

232. Pei, Y.F.; Zhang, L.; Liu, Y.; Li, J.; Shen, H.; Liu, Y.Z.; Tian, Q.; He, H.; Wu, S.; Ran, S.; et al. Meta-analysis of genome-wide association data identifies novel susceptibility loci for obesity. Hum. Mol. Genet. 2014, 23, 820-830. [CrossRef] [PubMed]

233. Kortenjann, M.; Nehls, M.; Smith, A.J.; Carsetti, R.; Schüler, J.; Köhler, G.; Boehm, T. Abnormal bone marrow stroma in mice deficient for nemo-like kinase, Nlk. Eur. J. Immunol. 2001, 31, 3580-3587. [CrossRef]

234. Supakankul, P.; Mekchay, S. Association of NLK polymorphisms with intramuscular fat content and fatty acid composition traits in pigs. Meat. Sci. 2016, 118, 61-65. [CrossRef] [PubMed]

235. Hasygar, K.; Hietakangas, V. p53- and ERK7-dependent ribosome surveillance response regulates Drosophila insulin-like peptide secretion. PLoS Genet. 2014, 10, e1004764. [CrossRef]

236. Yong, H.Y.; Koh, M.S.; Moon, A. The p38 MAPK inhibitors for the treatment of inflammatory diseases and cancer. Expert. Opin. Investig. Drugs 2009, 18, 1893-1905. [CrossRef] [PubMed]

237. Chen, C.; Nelson, L.J.; Ávila, M.A.; Cubero, F.J. Mitogen-Activated Protein Kinases (MAPKs) and Cholangiocarcinoma: The Missing Link. Cells 2019, 8. [CrossRef] [PubMed] 
238. Elkhawad, M.; Rudd, J.H.; Sarov-Blat, L.; Cai, G.; Wells, R.; Davies, L.C.; Collier, D.J.; Marber, M.S.; Choudhury, R.P.; Fayad, Z.A.; et al. Effects of p38 mitogen-activated protein kinase inhibition on vascular and systemic inflammation in patients with atherosclerosis. JACC Cardiovasc. Imaging 2012, 5, 911-922. [CrossRef]

239. Emami, H.; Vucic, E.; Subramanian, S.; Abdelbaky, A.; Fayad, Z.A.; Du, S.; Roth, E.; Ballantyne, C.M.; Mohler, E.R.; Farkouh, M.E.; et al. The effect of BMS-582949, a P38 mitogen-activated protein kinase (P38 MAPK) inhibitor on arterial inflammation: A multicenter FDG-PET trial. Atherosclerosis 2015, 240, 490-496. [CrossRef]

(C) 2020 by the authors. Licensee MDPI, Basel, Switzerland. This article is an open access article distributed under the terms and conditions of the Creative Commons Attribution (CC BY) license (http://creativecommons.org/licenses/by/4.0/). 